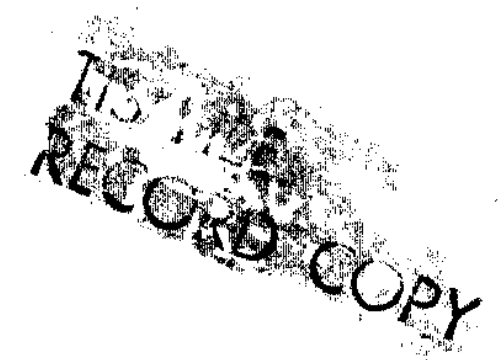

\title{
MATERIALS ASPECTS OF SRP WASTE STORAGE - CORROSION AND MECHANICAL FAILURE
}

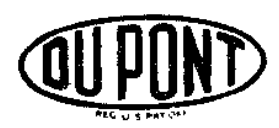

SAVANNAH RIVER LABORATORY AIKEN, SOUTH CAROLINA 29801 
This report was prepared as an account of work sponsored bv the United States Government. Neither the United States nor the United States Energy Research and Development Administration, nor any of their contractors, subcontractors, or their employees, makes any warranty, express or implied or assumes any legal liability or responsibility for the accuracy, completeness or usefulness of any information, apparatus, product or process disclosed, or represents that its use would not infringe privately owned rights.

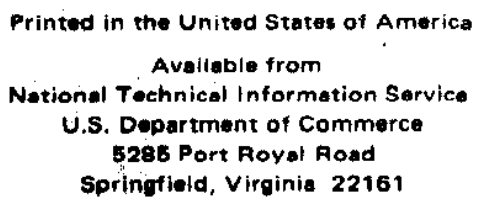

Price: Printed Copy $\$ 4.50$; Microfiche $\$ 3.00$ 
DP-1476

Distribution Category UC-25

\title{
MATERIALS ASPECTS OF SRP WASTE STORAGE - CORROSION AND MECHANICAL FAILURE
}

\author{
Compiled by \\ J. A. Donovan
}

Approved by

R. T. Huntoon, Research Manager

Nuclear Materials Division

Publication Date: November 1977

E. I. DU PONT DE NEMOURS AND COMPANY SAVANNAH RIVER LABORATORY AIKEN, SOUTH CAROLINA 29801

PREPARED FOR THE U.S. DEPARTMENT OF ENERGY UNDER CONTRACT AT/07-2)-1 


\section{ABSTRACT}

Studies were made on the causes of observed leaks in mild steel tanks used to store liquid waste from nuclear fuel reprocessing at the Savannah River Plant. Leaks were observed in the walls of some primary vesscls and in some cooling coils. The studies revealed that: wall leaks resulted from nitrate stress corrosion cracking caused by alkaline nitrate solution; and coil leaks resulted from pitting corrosion caused by diluted waste solutions during sludge removal. Stresses that caused wall cracking were residual stresses, primarily those produced during tank fabrication. Pitting of coils was caused by the concurrent dilution of nitrite in the waste supernate, and leaching of sulfate from the sludge. Results of these studies provided the bases for modifications in fabrication and operation of waste tanks. The modifications included:

- Selection of more stress corrosion resistant steels for tank fabrication,

- Heat treatment of newly fabricated tanks to relieve stresses,

- Operation of tanks at temperatures above the nil ductility transition temperature of the steel to preclude brittle fast. fracture,

- Operation of tanks at temperatures below specified upper limits to reduce incidence of nitrate stress corrosion cracking,

- Specification of limits on concentrations of nitrate, nitrite, and hydroxide ions in waste supernate to prevent stress corrosion cracking of walls. and

- Specification of limits on nitrite ion concentration in sludge slurry to prevent pitting corrosion of cooling coils. 


\section{CONTENTS}

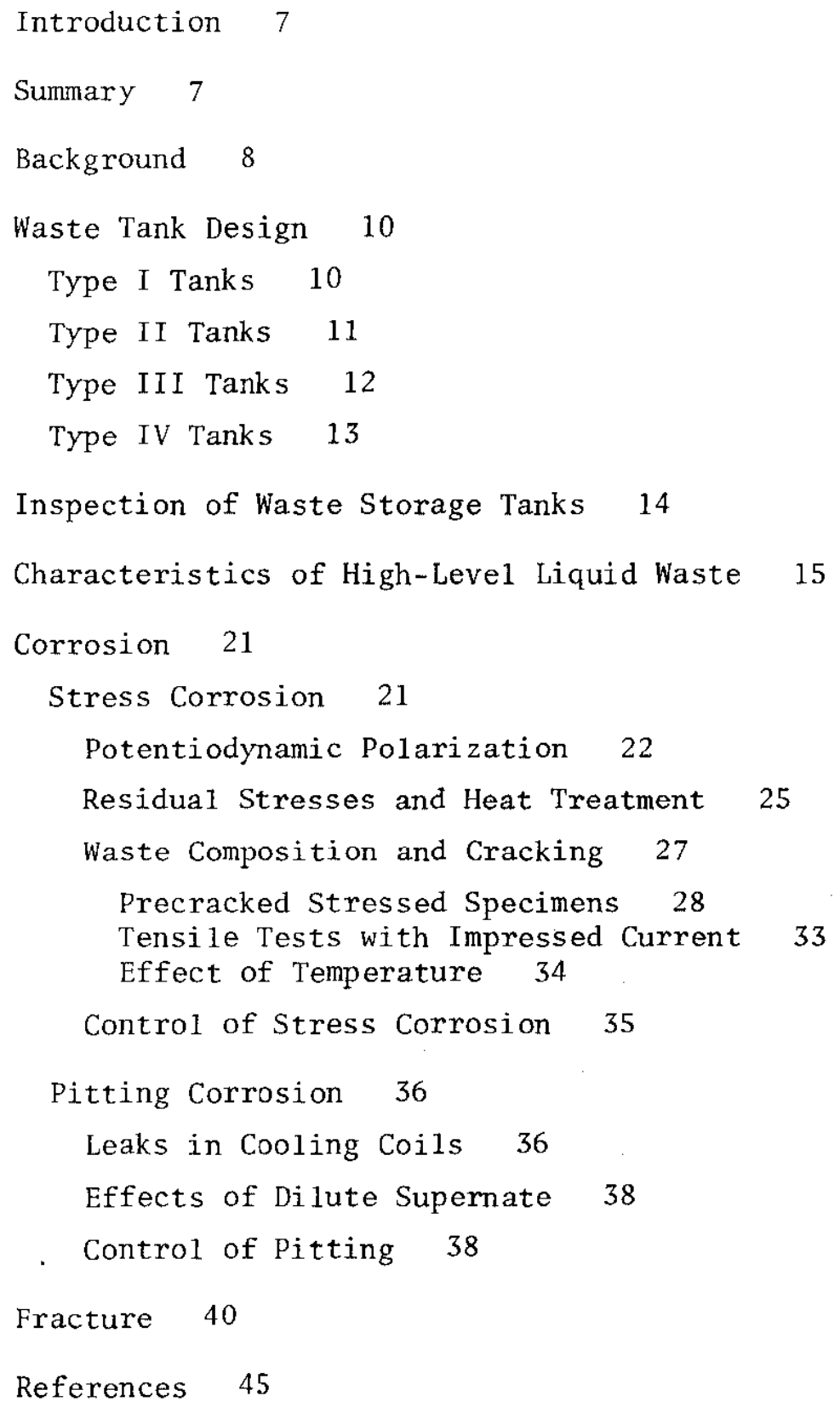




\section{LIST OF FIGURES}

1 High-Heat Waste (HHW) Processing in Tank Farm 1

2 Type I Waste Storage Tanks (1951-53) 11

3 Type II Waste Storage Tanks (1955-56) 11

4 Type III Waste Storage Tanks 12

5 Type IV Waste Storage Tanks 14

6 Schematic of Processes that Cause Stress Corrosion Cracking 22

7 Intergranular Cracking of A 285-B Steel 23

8 Potentiodynamic Polarization of A 285-B Steel in Various Solutions 25

9 Residual Stress in Butt We1ds 26

10 Modified WOL Specimen 29

11 Crack Length as a Function of Time 30

12 Tests on Influence of $\mathrm{NO}_{2}^{-}$and $\mathrm{OH}^{-}$on Crack Growth of A 285-B Steel in $5 \mathrm{M} \mathrm{NaNO}_{3} \quad 31$

13 Appearance of Fractures in Electrochemical Tensile Test 32

14 Effect of $\mathrm{OH}^{-}$Concentration on Electrochemical Tensile Test 33

15 Incidence of Cooling Coil Leaks, Tanks 1-9, 11-16 37

16 Perforated Upper Horizontal Cooling Coil, Tank 237

17 Electrochemical Pitting and Prevention in Dilute Supernate 39

18 Schematic Diagram of Toughness vs. Temperature for a Mild Steel 41 
LIST OF FIGURES (Contd)

19 NDTT Distribution for A285-C Stee1 42

20 Generalized Fracture Analysis Diagram 43 


\section{LIST OF TABLES}

I Inspections of Waste Tanks Since 1971 I

2 Chemical Composition of Fresh, High-Leve1 Liquid Waste 17

3 Radionuclide Composition of Fresh, High-Leve1 Liquid Waste 18

4 Concentration Range of Major Constituents of LHW Supernates 19

5 Concentration Range of Major Radioactive Constituents of LHW Supernates 19

6 Concentration Range of Major Constituents in Aged HHW Supernates 20

7 Concentration Range of Major Radioactive Constituents of Aged HHW Supernates 20

8 Effect of Heat Treatment on SCC 27

9 Effect of Composition on Crack Initiation Time and $\mathrm{K}_{\mathrm{SCC}} 29$

10 Effect of Temperature on Tensile Properties 35

11 Required Minimum $\mathrm{OH}^{-}$and $\mathrm{NO}_{2}^{-}$Concentrations in SRP Wastes 36

12 NDTT of Steels Used in Waste Tank Construction 44 


\section{MATERIALS ASPECTS OF SRP WASTE STORAGE - CORROSION AND MECHANICAL FAILURE}

\section{INTRODUCTION}

The wastes from the recovery of plutonium and uranium at the Savannah River Plant (SRP) are primarily alkaline nitrate solutions that contain many radioactive and nonradioactive components. The wastes are stored in large, near surface carbon steel tanks with multiple containment barriers to prevent leakage to the surrounding environment. Some of the tanks contain water-cooled coils to remove the heat produced by the decay of the radionuclides. The walls of the primary vessel in some of the tanks and some of the cooling coils have leaked, but for apparently different reasons. Nitrate stress corrosion cracking caused the observed leaks in the walls, and pitting corrosion due to exposure of the coils to dilute waste solutions during sludge removal campaigns caused most of the leaks in cooling coils.

This report reviews the performance of tanks used for interim storage of high level liquid waste at SRP and the materials deficiencies that have been experienced. The technical investigations to identify the causes of these deficiencies are summarized, and modifications in the construction of the tanks and in waste management that resulted from these studies are described. These modifications increase the integrity of the tanks, providing more secure containment.

\section{SUMMARY}

Nine of 16 tanks that were designed before 1960 have developed leaks in the walls of the primary vesse1 and leaked waste into the space between the primary vessel and the pan that provides secondary containment. The leaks apparently were caused by nitrate stress corrosion cracking. Since both a relatively high mechanical stress and an aggressive corrodent are required for stress corrosion cracking to occur, cracking can be avoided by controlling either factor to a safe range. Parallel experimental programs were undertaken to evaluate these factors and to establish appropriate means for their control.

Analyses and experimental studies demonstrated that the stresses that caused the cracking were residual stresses produced during fabrication, largely by nonuniform thermal expansion and 
contraction caused by welding. In laboratory tests residual stresses in large welded plates were reduced sufficiently by a stress-relief heat treatment that stress corrosion cracking did not occur even in $50 \% \mathrm{NaNO}_{3}$ solution -- a more aggressive solution than any SRP waste. Stress relief has been specified for all tanks designed after 1960 .

Continuing investigations of the chemical aspects of stress corrosion showed that fresh wastes from the fuel reprocessing plants are the most aggressive waste solutions; these solutions are highest in nitrate concentration. As the solutions age and are evaporated, the concentrations of nitrite and hydroxide increase. These ions inhibit nitrate stress corrosion. On the basis of laboratory test results, limits on the nitrate, nitrite, and hydroxide concentrations in the waste solutions are now specified so that the waste composition will be in ranges in which crack growth did not occur.

Penetration by pitting corrosion caused a high frequency of leaks in cooling coils in some waste tanks soon after sludge removal operations. Experimental evidence showed that the most likely series of events leading to coil leakage was 1) excessive dilution of the nitrite in the waste, 2) initiation of attack in crevices due to oxygen depletion cells, and 3) acceleration of the attack by sulfate dissolved from the sludge.

Pitting will be avoided in the future by assuring that sufficient nitrite is present in the liquid used for slurrying the sludge to permit it to be pumped out.

Laboratory test findings also resulted in the selection of improved steels for the construction of the tanks. Since 1960 the steels used have superior corrosion resistance, principally because they are stronger and have a slightly higher carbon content. The steels in the newest tanks (built after 1974) also have better toughness because the as-rolled plates were normalized (a special heat treatment performed at the steel mil1). The improved toughness essentially eliminates brittle fracture as a credible failure mode.

Brittle fracture may occur in mild stee1 under certain conditions of flaw size and temperature in relation to a toughness measure of the steel called the nil-ductility-transition temperature (NDTT), and the stress in relation to the yield stress. For a given flaw size and stress, brittle failure is possible if the temperature is sufficiently low in relation to the NDTT.

A survey of NDTT for as-rolled steels similar to those in earlier tanks indicates that $99 \%$ of the steel used probably has an NDTT less than $21^{\circ} \mathrm{C}$. The walls are maintained at temperatures above $21^{\circ} \mathrm{C}$ to minimize the probability of brittle failure in these waste tanks. 
BACKGROUND

Liquid radioactive wastes are produced at SRP primarily from the two nuclear fuel reprocessing operations in the $\mathrm{F}$ and $\mathrm{H}$ Areas. These wastes are divided into two categories, low heat and high heat, depending on the heat generation rate, and are stored retrievably in large subsurface tanks in these areas. ${ }^{1}$

Figure 1 illustrates schematically the high-heat waste process $^{1}$ in the waste tank farm. The waste from the reprocessing plant is received in a cooled tank. This fresh waste is aged from one to two years to permit solid material to settle and short-lived fission products to decay. During this period insoluble materials form a layer of sludge at the bottom of the tank. The sludge consists of oxides and hydroxides of manganese, iron, and some aluminum; small amounts of uranium, plutonium, and mercury; and most of the longer-1ived fission products originally in the irradiated fuel except cesium. After aging, the supernate solution, containing dissolved salts, including radioactive cesium, is transferred to a continuous evaporator. The concentrate from the evaporator is transferred to a cooled waste tank where the salts crystallize and settle as the liquid cools. The remaining supernate is returned to the evaporator for further concentration. This process continues until the liquid has been converted to a damp salt cake.

The low-heat waste is handled similarly to high-heat waste (HHW) except it is not necessarily aged before evaporation and cooling is not required.

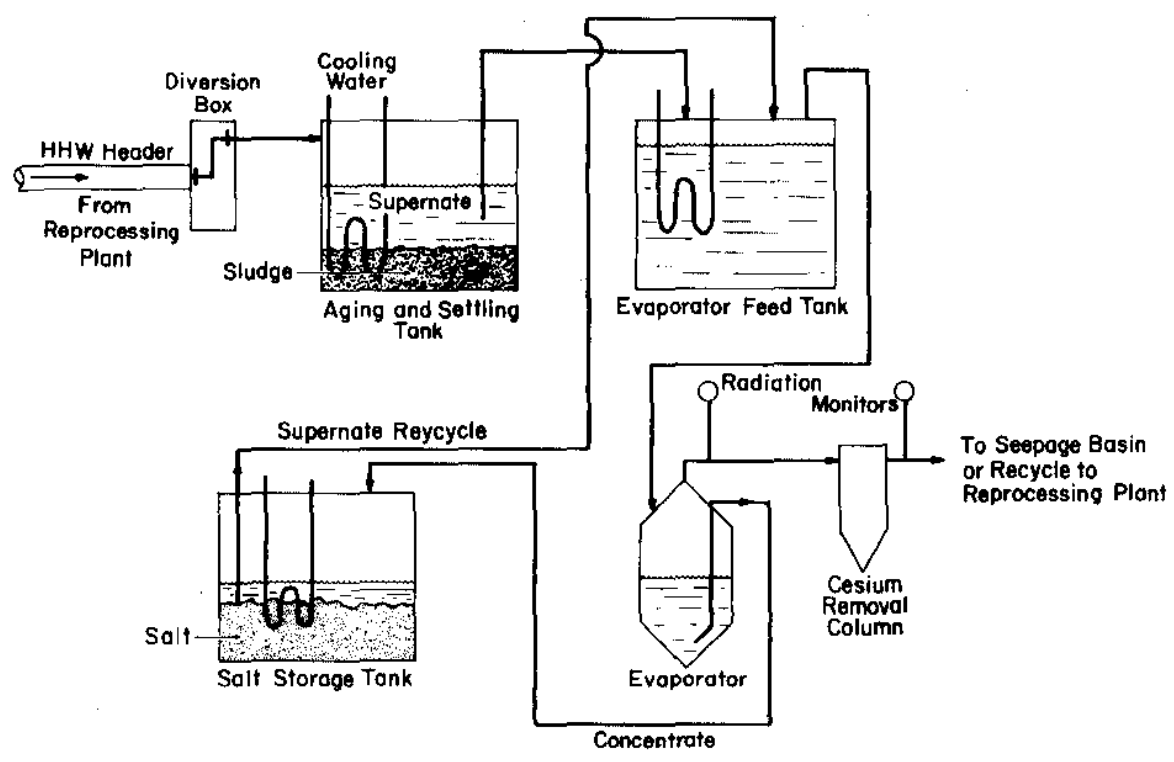

FIGURE 1. High-Heat Waste (HHW) Processing in Tank Farm 


\section{WASTE TANK DESIGN}

At present, SRP has 31 large subsurface tanks for the storage of liquid radioactive wastes, as sludge, supernatant liquid of various salt concentrations, and salt cake. Seventeen of these tanks are in $\mathrm{H}$ Area and 14 are in $\mathrm{F}$ Area. Two additional tanks are nearing completion in $\mathrm{H}$ Area, and 14 others ( 6 in $\mathrm{H}$ Area and 8 in $\mathrm{F}$ Area) are in various stages of construction.

All of the waste tanks are below ground, and are built of carbon steel and reinforced concrete, but they are of four somewhat different designs. ${ }^{1}$ Three designs (Types I, II, and III) have double steel walls and bottoms and forced water cooling systems and are used primarily for high-heat waste; the fourth design (Type IV) has a single steel wall directly supported by the encasing reinforced concrete, has no forced cooling, and is used primarily for low-heat waste.

\section{Type I Tanks}

The original 12 storage tanks constructed during 1951-1953 are designated Type I tanks. Tanks 1 through 8 were placed in F Area and Tanks 9 through 12 in H Area. Each primary tank holds 750,000 gallons, is 75 feet in diameter, and is 24-1/2 feet high. Figure 2 shows the essential features of Type I tanks, ${ }^{2}$ including the primary tank, the secondary pan, and the concrete support structure.

The primary container is a closed cylindrical tank with flat top and bottom constructed from half-inch-thick plate of ASTM A-285 Grade B carbon steel. The top and bottom are joined to the cylindrical side wall by curved knuckle plates. The primary tank is set in a circular pan of half-inch steel plate, 5 feet deep, and 5 feet larger in diameter than the tank. The secondary vesse1, the pan, thus provides an intervening annulus $2-1 / 2$ feet wide. The assembly of tank and pan is surrounded by a cylindrical reinforced concrete enclosure. Twelve concrete columns, each 2 feet in diameter, having flared capitals, and encased in half-inch steel plate, are installed within the primary tank to support the flat concrete roof. Thirty-six parallel cooling water circuits ("coils") cool the contents of each tank.

Forced ventilation of the tank interior is providod by a small blower exhausting through a condenser and fiberglass filter. Dehumidification equipment consisting of a fan, a heater, and ductwork is installed at each tank to keep the annular space dry. The design intent is to maintain the annular space temperature above the dew point to minimize external corrosion. Similar equipment is provided for both Type II and Type III tanks. 


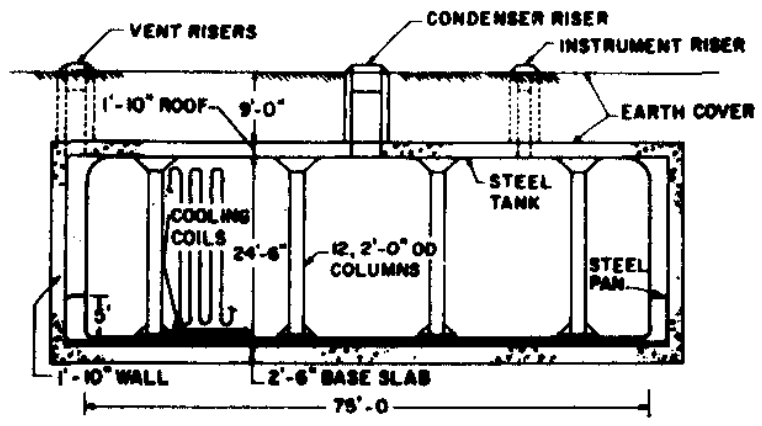

Figure 2. Type I Waste Storage Tanks $(1951-53)^{2}$

(F Area, Tanks 1-8; H Area, Tanks 9-12)

\section{Type II Tanks}

Tanks 13 through 16, constmucted in H Area in 1955-1956, are designated Type II tanks. Figure 3 is a cross section diagram of this type. ${ }^{2}$ Each primary tank holds $1,030,000$ gallons, is 85 feet in diameter, and 27 feet high.

The primary container for a Type II tank consists of two concentric steel cylinders assembled with a flat bottom and a flat top into a form somewhat like a doughnut. The top and bottom are joined to the outer cylinder by rings of curved knuckle plates. The inner cylinder is flared at the top to accommodate the roof support column. This cylinder is joined to the flat steel top with a continuous butt weld and to a base fastened to the bottom with a continuous "T" weld. ASTM A-285 Grade B carbon steel plates used in the construction of the tank are of various thicknesses, as follows:

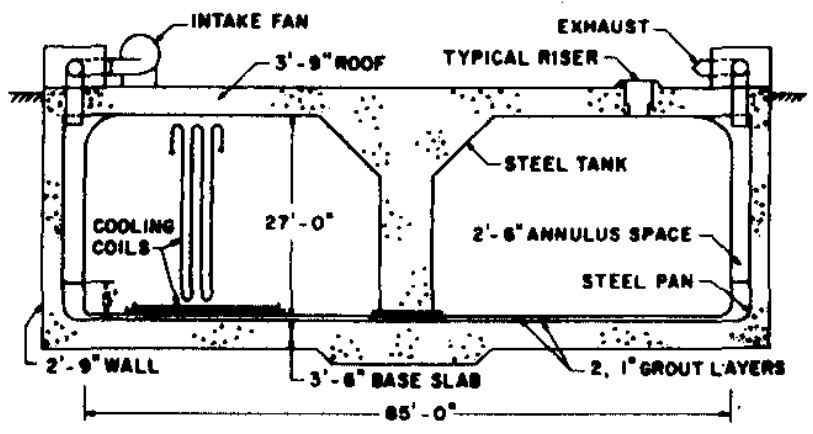

FIGURE 3. Type II Waste Storage Tanks $(1955-56)^{2}$

(H Area, Tanks 13-16) 
Top and bottom plates

Upper knuckle plates

Wa11 plates

Lower knuck1e plates
$1 / 2$ in.

$9 / 16$ in.

$5 / 8$ in.

$7 / 8$ in.

The primary tank is set on a one-inch sand bed within a circular pan of half-inch steel, 5 feet deep and 5 feet larger in diameter than the tank. The tank and pan assembly is surrounded by a cylindrical reinforced-concrete enclosure. Cooling is provided for each Type II tank by 44 parallel cooling water coils. A condenser, fiberglass filter, and blower or exhauster are installed on the tank vent.

\section{Type II I Tanks}

The tanks constructed most recently are designated as Type III. Figure 4 depicts the basic Type III structural form. Seven Type III tanks are in service. Four of them, Tanks 29 through 32, were built in H Area in 1967-1970; two others, Tanks 33 and 34, were built in F Area in 1969-1972; and Tank 35 in H Area was completed in 1977. Sixteen additional tanks of this type are under construction. Each primary tank holds 1,300,000 gallons, is 85 feet in diameter and 33 feet high.

The Type III tank design was developed after an investigation into the causes for leaks from Type I and Type II primary tanks.

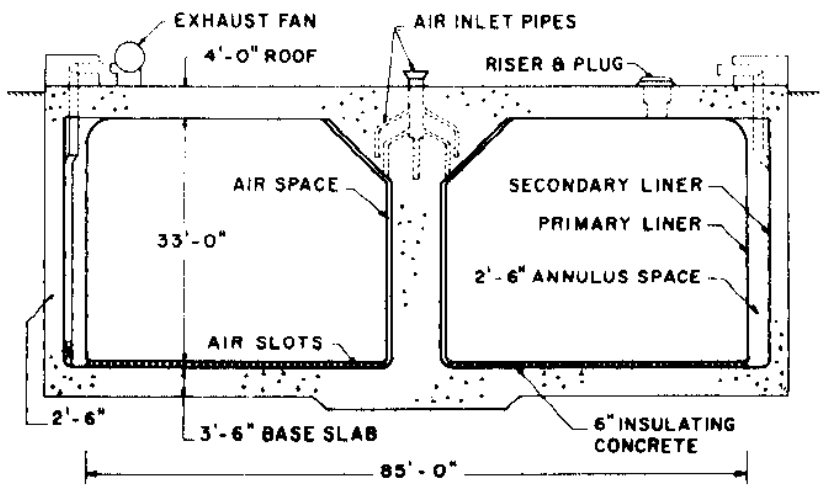

FIGURE 4. Type III Waste Storage Tanks ${ }^{2}$

[F Area, Tanks 33-34 (1969-72), Tanks 25-28 (1975-78), Tanks 44-47 (1977-80); H Area, Tanks 29-32 (1967-70), Tanks 35-37 (1974-77), Tanks 38-43 (1976-80)] 
The conclusions of the investigation were that the primary leakproducing mechanism was stress corrosion cracking at sites in or near the weld seams, and that stress relieving after fabrication should eliminate the cracking. ${ }^{3},{ }^{4}$ For the Type III tanks, all components of the primary tank below the maximum liquid level were stress relieved in place after all burning, cutting, welding, and other high temperature work (other than roof attachments) had been completed. Full stress relief, at $1100^{\circ} \mathrm{F}$, was accomplished in accordance with the requirements of the ASME Boiler and Pressure Vesse1 code. ${ }^{5}$ Tanks built before 1974 were constructed of as-rolled ASTM A-516 Grade 70 steel, which is stronger and more resistant to stress corrosion than A 285-B stee1. After 1974 either A 516-70 or ASTM A 537 Class I steel that is normalized to provide greater fracture toughness is being used.

The form of the Type III tanks is similar to the ring-1ike shape of the Type II tanks. Each primary vesse1 is made of two concentric cylinders joined to washer-shaped top and bottom plates by curved knuckle plates.

The steel secondary vessel is 5 feet larger in diameter than the primary, providing a $2-1 / 2$ foot annulus. Tank side walls rise to the full height of the primary tank, in contrast to the "pans" of Types I and II tanks. The nested two-vessel assembly is surrounded by a cylindrical reinforced concrete enclosure. A demister, a condenser, a HEPA filter, and an exhaust blower are installed in series on the tank vent.

Cooling is provided in the first seven Type III tanks (29-35) by removable coil assemblies inserted through openings (risers) in the tank tops. For liquid service (Tanks 32 and 35 ) bundles of closely spaced pipes are used; for tanks accumulating solid salts deployable coil assemblies are used to distribute the pipes more widely within the tanks. Tank 36 and all subsequent tanks will have permanently installed coils uniformly distributed to provide more effective cooling of salt.

\section{Type IV Tanks}

Tanks 17 through $24^{*}$ are designated Type IV tanks. These tanks were designed for storage of waste that does not require auxiliary cooling. Tanks 17 through 20 were built in $F$ Area in 1958, and Tanks 21 through 24 were built in H Area in 1959-1961.

* Tank 23 is not strictly in separations - process waste storage service. It is used to hold contaminated water from the Receiving Basin for off-Site Fuel and other sources prior to treating it in the Cs-removal column for subsequent release to seepage basins. 
Each tank holds 1,300,000 ga11ons, is 85 feet in diameter and 34 feet high (Figure 5 ). ${ }^{2}$

Each Type IV tank is basically a steel-lined, prestressedconcrete tank in the form of a vertical cylinder with a domed roof. ASTM A 285 Grade B (F-Area tanks) or A 212 Grade B (H-Area tanks) carbon steel plates, $3 / 8$ inch thick, form the cylindrical sides and flat bottom portion of the stcol liners. The knuckle plates at the juncture of the bottom and the side wall are 7/16 inch thick. No secondary steel pan was provided for these tanks. Leak detection for the bottoms of these tanks is provided by a radial array of channels in the concrete foundation under the tank that drain to a sump outside the periphery of the tank wall.

\section{INSPECTION OF WASTE STORAGE TANKS}

Before being placed in service, each series of tanks underwent increasingly more exhaustive inspections as new procedures became available. The evolution of these inspection requirements is described in Reference 1 . After a tank is in service, inspection of the tanks becomes more difficult because of radiation and contamination problems. However, techniques have been developed for remote inspection and evaluation of the waste tanks. These techniques include visual inspection by means of a periscope, and corrosion specimens (including excision of a portion of a tank wa $11^{6}$ and a failed cooling coil). ${ }^{7}$ The inspection techniques are described in Reference 1.

$3^{\prime} 8^{\prime \prime}$ EARTH COVER

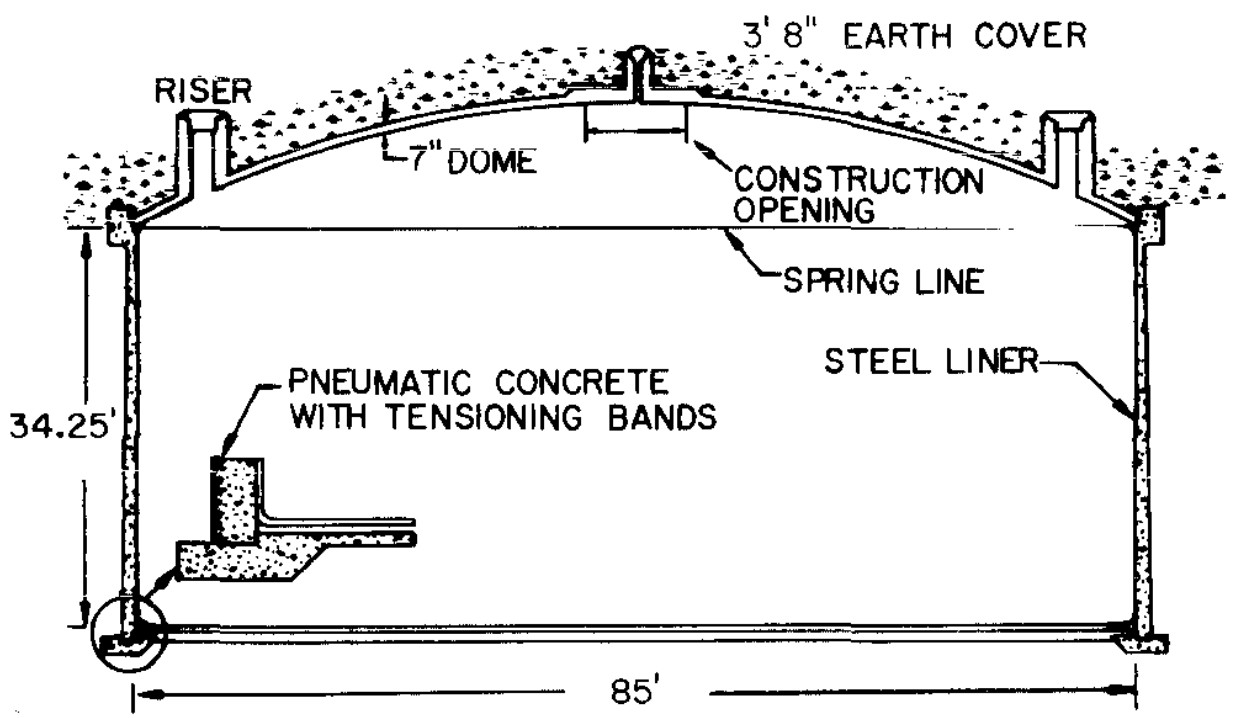

FIGURE 5. Type IV Waste Storage Tanks ${ }^{2}$

[F Area, Tanks 17-20 (1958); H Area, Tanks 21-24 (1962)] 
Since 1959, the most important and recurrent waste tank inspections have been visual surveys in the annular spaces, and, to a lesser extent, inside the primary tanks.

A continuing, comprehensive waste tank inspection program ${ }^{1}$ was begun in November 1971 to provide an up-to-date evaluation of the condition of the waste tanks. Periscope inspections, wall thickness measurements, and corrosion specimens indicate that no significant general corrosion of the carbon steel tanks is occurring. Pitting corrosion, which was observed in an excised section of a Tank 2 cooling coil, ${ }^{7}$ has not been observed during periscope inspections of the tank walls, although broad, shallow pits were observed on the sample removed from Tank $16 .^{6}$

A summary of the inspections made between November 1971 and July 1977 is shown in Table 1.

Since 1957 when the first leak in the waste tanks occurred, nine tanks have leaked radioactive waste into the annular space. One tank (Tank 16) has leaked a minor amount of waste to the surrounding ground ${ }^{8}$ and this tank has been removed from active use in storing liquid waste. The leaks in the other tanks have self-sealed by forming a salt crust. Two of the Type IV tanks have indications of radioactivity in the sumps. No leak sites have been located; this observation of radioactivity proved to be caused by contaminated condensate seeping down the outside surface of the steel liner. ${ }^{9}$

Most of the observed leaks have been close to weld beads, oriented perpendicular to the weld, but seldom extending through it. The number of cracks in the tanks range from one to approximately 300. The time for cracks to develop ranged from a minimum of several months to many years after the tanks were placed in service. All leaks have been in tanks that were not stress relieved (Types I and II).

\section{CHARACTERISTICS OF HIGH-LEVEL LIQUID WASTE}

The liquid waste received in the waste tanks is made up of many different waste streans from the spent fuel reprocessing plants. The chemical composition of the major components of a composite high-level liquid waste stream (containing both lowheat and high-heat wastes) is given in Tab1e $2 .^{1}$ This is the waste referred to as "fresh $221-H^{\prime \prime}$ later in the text. Table 3 shows the concentrations of radionuclides in the waste from irradiated components that have been cooled six months before being reprocessed. ${ }^{1}$ Both the chemical and radionuclide composition of the waste change as the waste ages. The major changes are: 
TABLE ?

Inspections of Waste Tanks Since $1971^{a}$

\begin{tabular}{|c|c|c|c|c|c|c|}
\hline \multirow{2}{*}{$\begin{array}{l}\text { Tank } \\
\text { No. }\end{array}$} & \multirow{2}{*}{$\begin{array}{l}\text { Date } \\
\text { in } \\
\text { Service }\end{array}$} & \multirow{2}{*}{$\begin{array}{l}\text { First } \\
\text { Leak } \\
\text { Observed }\end{array}$} & \multicolumn{4}{|c|}{ Tupe of Inopection or Measurement } \\
\hline & & & Periecope & $\begin{array}{l}\text { Direct } \\
\text { Photos }\end{array}$ & $\begin{array}{l}\text { Waltb } \\
\text { Thickness }\end{array}$ & $\begin{array}{l}\text { Temperature } \\
\text { Profite }\end{array}$ \\
\hline \multicolumn{7}{|c|}{ Double-Wall } \\
\hline 1 & 1954 & 1969 & $72,73,74$ & $75,76,77$ & 77 & 74,75 \\
\hline 2 & 1955 & - & $72,73,76$ & $73,75,76,77$ & $72,73,77$ & 73,74 \\
\hline 3 & 1956 & - & $72,73,74,75,76$ & $73,75,76,77$ & 77 & 74,75 \\
\hline 4 & 1961 & - & $72,73,74,76$ & $75,76,77$ & 73,77 & \\
\hline 5 & 1959 & - & $72,73,74$ & $73,75,76,77$ & 73,77 & \\
\hline 6 & 1964 & - & $72,73,76$ & $75,76,77$ & 74,77 & \\
\hline 7 & 1954 & - & 72,73 & $75,76,77$ & 74,77 & 73,74 \\
\hline 8 & 1956 & - & $72,73,76$ & $73,75,76,77$ & 73,77 & $73,74,75$ \\
\hline 9 & 1955 & 1957 & 72,73 & $74,75,76,77$ & 77 & 74 \\
\hline 10 & 1955 & 1959 & $72,76,77$ & $74,75,76$ & 77 & 75 \\
\hline 11 & 1955 & 1974 & $72,73,74$ & $\begin{array}{l}73,74,75 \\
76,77\end{array}$ & 73,77 & 73,74 \\
\hline 12 & 1956 & 1974 & $72,74,77$ & $74,75,76,77$ & $72,73,77$ & 73,74 \\
\hline 13 & 1956 & 1977 & $72,73,75$ & $74,75,76,77$ & 74,77 & 73 \\
\hline 14 & 1957 & 1959 & $72,73,74,76$ & $75,76,77$ & 77 & 74 \\
\hline 15 & 1960 & 1972 & $72,73,74$ & $74,75,76,77$ & 77 & \\
\hline 16 & 1959 & 1959 & $72,73,74,75,77$ & $74,75,76$ & 77 & 75 \\
\hline 29 & 1971 & - & $72,73,74$ & $74,75,76,77$ & $73,74,77$ & $73,74,75$ \\
\hline 30 & 1974 & - & 72 & $74,75,76,77$ & 75,77 & \\
\hline 31 & 1972 & - & $72,73,75$ & $74,75,76,77$ & 77 & $73,74,75$ \\
\hline 32 & 1971 & - & 72 & $74,75,76,77$ & 77 & $73,74,75$ \\
\hline 33 & 1974 & - & 75 & $74,75,76,77$ & 77 & 74,75 \\
\hline 34 & 1972 & - & $72,73,75$ & $74,75,76,77$ & 77 & $73,74,75$ \\
\hline 35 & 1977 & - & & 77 & 77 & \\
\hline \multicolumn{7}{|c|}{ Single-Wall } \\
\hline 17 & 1961 & - & $72,74,76$ & & & \\
\hline 18 & 1959 & - & 72,75 & & & 74 \\
\hline 19 & 1961 & - & $72,74,75$ & & & 74 \\
\hline 20 & 1960 & - & $72,74,76$ & & & 74 \\
\hline 21 & 1961 & - & $71,74,75,76$ & & 73 & 74,75 \\
\hline 2.2 & 1965 & - & $71,72,73,74,76$ & & 74 & 75 \\
\hline 23 & 1963 & - & $72,75,76$ & 75 & 73 & \\
\hline 24 & 1963 & - & 72,73 & & & 73 \\
\hline
\end{tabular}

Observations ${ }^{b}$

Small waste salt deposit in annulus pan. No source found. No significani change since previous inspections.

Good condition. No evidence of lcakage. Good condition. No evidence of leakage. Good condition. No evidence of leakage. Good condition. No evidence of leakage. Good condition. No evidence of leakage. Good condition. No evidence of I eakage. Good condition. No evidence of leakage. Approximately 9 inches of waste salt in annulus pan. No source found.

Approximately 2 inches of waste salt in annulus pan. No source found.

Water inleakage through riser wall; nonradioactive solids on wall; salt deposit at one leak site.

Salt deposit at one leak site.

Salt deposit at one leak site.

Approximately $14 \mathrm{in}$. of waste salt in annulus pan; approximately 50 leak sites. About 15 leak sites.

Approximately $15 \mathrm{in}$. waste sait in amulus pan. The large number of leak sites has caused the tank to be empticd dowr to a sludge level; approxinately 300 leak sites have been identified.

Good condition. No evidence of leakage.

Good condition. No evidence of ieakigu.

fiood condition. No evidence of leakagc.

Goud condition. Wo evidence of lnakage.

Good condition. No evidence of leakage.

Good condition. Nu evicience of licakage.

Good condition. No evidence of leakage.

Good condition. Slight rusting only.

Good condition. Siight rusting only.

tood condition. Slight rusting only.

Good condition. Slight rusting only.

Good condition. Slight rusting only.

Good condition. Slight misting only.

Evidence of ground water seeprage through fault (s) in dome.

Good condition. Slight rusting only.

Good condition. Slight rusting.

Evidence of ground water seepage through fault (s) in dome.

a. Numbers 72 through 77 denote years in which inspection was made.

b. A11 wall and botton steel measurements to date compare favorabiy with mill rolling specifications for the plates, indicating no loss of thickness. 
- Radiolytic decomposition of the waste. The major effect of this radionuclide decomposition is the slow reduction in the $\mathrm{NaNO}_{3}$ concentration with an equivalent increase in $\mathrm{NaNO}_{2}$ concentration. After 5 to 10 years, the $\mathrm{NaNO}_{2}$ concentration approaches the residual $\mathrm{NaNO}_{3}$ concentration.

- A slow reduction in the $\mathrm{NaOH}$ concentration due to reaction with $\mathrm{CO}_{2}$ absorbed from air, forming $\mathrm{Na}_{2} \mathrm{CO}_{3}$.

- Decay of radionuclides.

- Separation of the waste into sludge and supernate fractions. The sludge settles to the bottom of the tank and contains most of the insoluble radionuclides.

The sludge is composed primarily of oxides and hydroxides of manganese, iron, and, to a lesser degree, aluminum. It contains most of the fission products originally present in the irradiated fuel except cesium, and essentially all of the actinides. The sludge also contains a significant quantity of mercury.

\section{TABLE 2}

Chemical Composition of Fresh High-Level Liquid Waste

\begin{tabular}{ll} 
Constituent & \multicolumn{2}{l}{$\begin{array}{l}\text { Concentra } \\
\mathrm{NaNO}_{3}\end{array}$} \\
$\mathrm{NaNO}_{2}$ & 3.3 \\
$\mathrm{NaAl}(\mathrm{OH})_{4}$ & 0.5 \\
$\mathrm{NaOH}$ & 1 \\
$\mathrm{Na}_{2} \mathrm{CO}_{3}$ & 0.1 \\
$\mathrm{Na}_{2} \mathrm{SO}_{4}$ & 0.3 \\
$\mathrm{Fe}(\mathrm{OH})_{3}$ & 0.07 \\
$\mathrm{MnO}_{2}$ & 0.02 \\
$\mathrm{Hg}(\mathrm{OH})_{2}$ & 0.002 \\
Other Solids & $0.13^{a}$
\end{tabular}

a. An average molecular weight of 60 is assumed. 
TABLE 3

Radionuclide Composition of Fresh ${ }^{\alpha}$ High-Level Liquid Waste

\begin{tabular}{|c|c|c|c|}
\hline Radionuclide & Activity, Ci/gal & Radionuclide & Activity, Ci/gal \\
\hline${ }^{144} \mathrm{Ce}-{ }^{144} \mathrm{Pr}$ & 68 & ${ }^{241} \mathrm{Am}$ & $1 \times 10^{-3}$ \\
\hline${ }^{95} \mathrm{Zr}$ & 60 & ${ }^{99} \mathrm{Tc}$ & $5 \times 10^{-4}$ \\
\hline${ }^{91} Y$ & 47 & ${ }^{239} \mathrm{Pu}$ & $3 \times 10^{-4}$ \\
\hline${ }^{89} \mathrm{Sr}$ & 36 & ${ }^{154} \mathrm{Eu}$ & $1 \times 10^{-4}$ \\
\hline${ }^{95} \mathrm{Nb}$ & 15 & ${ }^{93} \mathrm{Zr}$ & $1 \times 10^{-4}$ \\
\hline${ }^{141} \mathrm{Ce}$ & 12 & $240 \mathrm{Pu}$ & $6 \times 10^{-5}$ \\
\hline${ }^{147} \mathrm{Pm}$ & 12 & ${ }^{135} \mathrm{Cs}$ & $4 \times 10^{-5}$ \\
\hline${ }^{103} \mathrm{Ru}$ & 10 & ${ }^{126} \mathrm{Sn}-{ }^{126} \mathrm{Sb}$ & $1 \times 10^{-5}$ \\
\hline${ }^{106} \mathrm{Ru}-{ }^{106} \mathrm{Rh}$ & 4 & ${ }^{79} \mathrm{Se}$ & $1 \times 10^{-5}$ \\
\hline${ }^{90} \mathrm{Sr}$ & 3 & ${ }^{23}{ }^{3} \mathrm{U}$ & $2 \times 10^{-6}$ \\
\hline${ }^{137} \mathrm{Cs}$ & 3 & ${ }^{129} \mathrm{I}$ & $1 \times 10^{-6}$ \\
\hline${ }^{129} \mathrm{Te}$ & 2 & ${ }^{23}{ }^{8} \mathrm{U}$ & $6 \times 10^{-7}$ \\
\hline $127 \mathrm{Te}$ & 2 & ${ }^{107} \mathrm{Pd}$ & $5 \times 10^{-7}$ \\
\hline${ }^{134} \mathrm{Ce}$ & 1 & ${ }^{237} \mathrm{~Np}$ & $4 \times 10^{-7}$ \\
\hline${ }^{151} \mathrm{Sm}$ & $8 \times 10^{-2}$ & ${ }^{152} \mathrm{Eu}$ & $2 \times 10^{-7}$ \\
\hline${ }^{2}{ }^{8} \mathrm{Pu}$ & $1 \times 10^{-2}$ & ${ }^{242} \mathrm{Pu}$ & $6 \times 10^{-8}$ \\
\hline${ }^{241} \mathrm{Pu}$ & $2 \times 10^{-3}$ & ${ }^{158} \mathrm{~Tb}$ & $6 \times 10^{-8}$ \\
\hline $2{ }^{44} \mathrm{Cm}$ & $1 \times 10^{-3}$ & ${ }^{235} \mathrm{U}$ & $3 \times 10^{-8}$ \\
\hline
\end{tabular}

a. After reprocessing fuel that has been cooled six months after discharge from reactor. 
The supernate portion of the liquid waste after aging contains dissolved salts including radioactive cesium nitrate. This supernate is transferred to an evaporator for dewatering, and the concentrate from the evaporator is transferred to a cooled waste tank where any suspended salts settle. Cooling causes additional salt to crystallize. The supernate is returned to the evaporator for further concentration. This process is repeated until the volume of liquid remaining is too small for ready removal and this portion of the waste has been converted to damp salt cake. The salt produced by evaporation of this aged supernate consists of $\mathrm{NaNO}_{3}, \mathrm{NaNO}_{2}, \mathrm{NaOH}, \mathrm{Na}_{2} \mathrm{CO}_{3}$, and $\mathrm{NaAl}(\mathrm{OH})_{4}$.

Because of these changes in chemical and radionuclide composition, the composition of the wastes in individual tanks varies widely depending on the detailed history of its contents. For this reason, the composition of the waste contained in the tanks is analyzed periodically. The concentration ranges of the major components and radionuclides in the uncooled tanks are given in Tables 4 and 5 , respectively. ${ }^{10}$

TABLE 4

Concentration Range of Major Constituents of LHW Supernates

Constituent Concentration, $M$

$\mathrm{Na}^{+} \quad 0.2-11.0$

$\mathrm{OH}^{-} \quad 0.06-7.9$

$\mathrm{NO}_{3}^{-} \quad 0.2-2.8$

$\mathrm{Al}(\mathrm{OH})_{4}^{-} \quad 0.01-1.1$

TABLE 5

Concentration Range of Major Radioactive Constituents of LHW Supernates

Constituent Concentration Range, $\mathrm{Ci} / \mathrm{gal}$

${ }^{13{ }^{4}} \mathrm{Cs} \quad<6 \times 10^{-6}-10^{-2}$

${ }^{137} \mathrm{Cs} \quad 5 \times 10^{-5}-2.2$

${ }^{144} \mathrm{Ce} \quad<8 \times 10^{-5}-10^{-2}$

${ }^{103} \mathrm{Ru} \quad<3 \times 10^{-3}-10^{-2}$

${ }^{106} \mathrm{Ru} \quad<5 \times 10^{-5}-4 \times 10^{-2}$

${ }^{90} \mathrm{Sr} \quad 8 \times 10^{-7}-10^{-5}$

${ }^{238} \mathrm{Pu} \quad 7 \times 10^{-6}-10^{-4}$ 
Any plutonium found in the supernate is probably due to the suspension of colloidal particles; otherwise, the plutonium and strontium segregate mostly in the sludge, and the cesium in the supernate and salt. and 7.31

Similar data for $\mathrm{HHW}$ in cooled tanks are given in Tables 6

Throughout the text of this report, reference is made to various compositions of synthetic wastes, e.g., "l1/12" or "1." These are designations of simulated wastes of the composition in the indicated waste tank at the time of the specific experiment. The reference cited should be consulted for the actual composition used.

TABLE 6

Concentration Range of Major

Constituents in Aged HHW Supernates

Constituent Concentration, $M$

$\mathrm{Na}^{+} \quad 4.0-12.5$

$\mathrm{NO}_{3}^{-} \quad 1.6-6.4$

$\mathrm{NO}_{2}^{-} \quad 0.2-3.2$

$\mathrm{A} 1(\mathrm{OH})_{4}^{-} \quad 0.4-1.6$

$\mathrm{OH}^{-} \quad 0.8-6.3$

TABLE 7

Concentration Range of Major Radioactive Constituents of Aged HHW Supernates

\begin{tabular}{lll} 
Constituent & \multicolumn{2}{c}{ Concentration Range, Ci/gal } \\
${ }^{134} \mathrm{Cs}$ & 0.2 & -4.6 \\
${ }^{1{ }^{7}} \mathrm{Cs}$ & 1.7 & -44 \\
${ }^{103} \mathrm{Ru}$ & $\mathrm{ND}$ & -0.2 \\
${ }^{89} \mathrm{Sr}$ & $<10^{-6}$ & $-3 \times 10^{-5}$ \\
${ }^{90} \mathrm{Sr}$ & $2 \times 10^{-4}-4 \times 10^{-3}$
\end{tabular}


CORROSION

Four distinct forms of corrosion attack may be observed in systems such as the waste tanks.

- Genera1 corrosion, the surface is attacked uniformly resulting in a gradual thinning of the structure.

- Pitting, the surface is attacked at very localized sites forming relatively deep pits or crevices. Pitting may cause very rapid penetration of the structure.

- Beachline attack, the metal is attacked more rapidly at the liquid-air (vapor) interface.

- Stress corrosion cracking (SCC), under the influence of an imposed stress and a slightly corrosive environment, the metal cracks at an imposed load much lower than its normal tensile strength.

Significant general corrosion has not been observed in the waste tanks as evidenced by the inspection program (both wall thickness measurements and direct observation), as we11 as by the performance of in-tank corrosion coupons.

Apparent corrosion cracking has been observed in six of the nine tanks in which salt deposits have been found in the annular space; SCC is presumed to be responsible for the leaks in the other three. Pitting, and possibly beachline attack, has caused leaks in about $10 \%$ of the cooling coils installed in Types I and II tanks. ${ }^{7}$ As described below, these corrosion mechanisms have been studied in the laboratory in an effort to select better materials of construction for new tanks and to control operating conditions to prevent additional failures.

\section{Stress Corrosion}

Stress corrosion cracking occurs in many metals and alloys due to the combined action of corrosion and stress. Neither significant corrosion nor stress alone would cause structural failure, but together they can. Figure 6 schematically shows the processes involved.

Mild steels (a generic name for a class of steels that contains less than about $0.3 \%$ carbon) are susceptible to SCC in nitrate solutions as well as in caustic solutions and several other environments. ${ }^{12}$ The precise mechanism of this form of failure is not universally agreed upon, but it is no doubt related to the fact that in a crevice or a crack the chemistry of the 


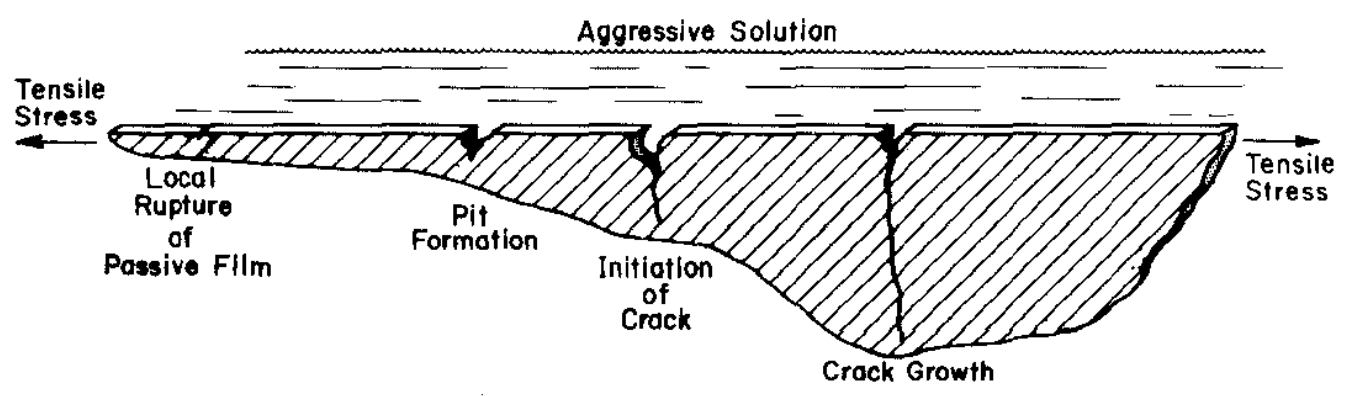

\section{FIGURE 6. Schematic of Processes that Cause Stress Corrosion Cracking}

system can be very different from that in the bulk solution. The most generally accepted mechanism is that the stress maintains a crevice in which the solution is agressive towards the metal. The chemistry at the crack tip has been shown to be significantly different by measurements of the $\mathrm{pH}$ - an indication of the concentration of hydrogen ions or the relative concentration of acid. Laboratory measurements have shown the $\mathrm{pH}$ in the crack tip region to be about 3 , acid, while the bulk solution was near neutral, a $\mathrm{pH}$ of $7 .{ }^{13}$ A solution with a $\mathrm{pH}$ of 3 readily corrodes mild steel.

A characteristic of this type of cracking is that it is intergranular. That is, the grain boundaries of the metal are preferentially attacked. Figure 7 shows the path of a $\mathrm{NO}_{3}^{-}$SCC in $A$ 285-B steel, ${ }^{14}$ compared with the crack found in the sample from Tank 16. This evidence, along with electrochemical behavior of the steel, as described in the following section, indicates that the cracking in waste tanks has been caused by nitrate stress corrosion.

\section{Potentiodynamic Polarization}

Corrosion of a metal requires transfer of electrons (current flow) between the anodic (oxidation) and cathodic (reduction) sites. Determination of the current density of a specimen in solution as a function of applied potential provides information about the maximum corrosion current, the system's tendency to corrode or passivate, and the open circuit potential.

Polarization curves, current density versus potential, for actual radioactive waste and synthetic waste solutions were practically the same (Figure 8 ) indicating a similar electrochemistry and, therefore, similar corrosion characteristics. ${ }^{11}$ Because of this similarity, corrosion investigations could be conducted with synthetic (nonradioactive) waste solutions instead 
of radioactive solutions, which greatly simplifies and expedites the experimental procedures.

The low current flow in the region between 0 and $0.3 y$ in Figure 8 indicates a passive system with low corrosion rates; between 0 and $-0.2 \mathrm{~V}$, coxrosion wrents are much higher and the comrosion systom is active. An activemassive transition as show is characteristic of systems susceptible to stress corrosion cracking.

The open circuit potential, the potential at zero current, was measured fox several waste tanks and was in the range -0.44 to $-0.064 \mathrm{~V}$ vs. saturated calonel electrode. This is within the range where nituate SCC is known to occur $(-0.3$ to $1.1 V)$ and is not in the range for caustic cracking $(-0.8$ to -1.00$)$. I

Another difference between $\mathrm{NO}_{3}^{-}$and $\mathrm{OH}^{-} \mathrm{SCC}$ is that $\mathrm{NO}_{3}^{-3}$ cracking car occur at temperatures less than $100^{\circ} \mathrm{C}$ while of $\mathrm{scC}$ generally occurs only at temperatures greater than $100^{\circ} \mathrm{C} .{ }^{15}$ The supernate that cracked the tanks was at tempexatures less than $100^{\circ} \mathrm{C}$. On the basis of the open-circut potential and temperature of the waste, the observed cracking is caused by nitrote and not by hydraxide stress corrosion.

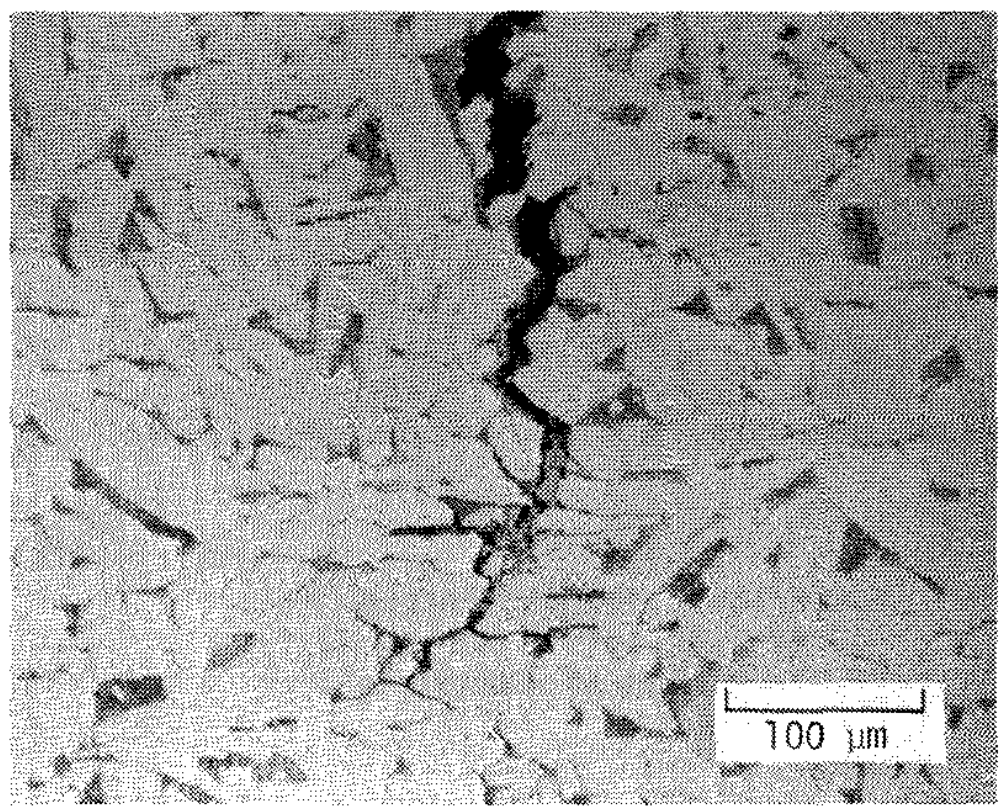

a. Cracking in Constant-Current Tensile Test

FrouRE 7 . Intergranular Cracking of $A 285-B$ Steel 


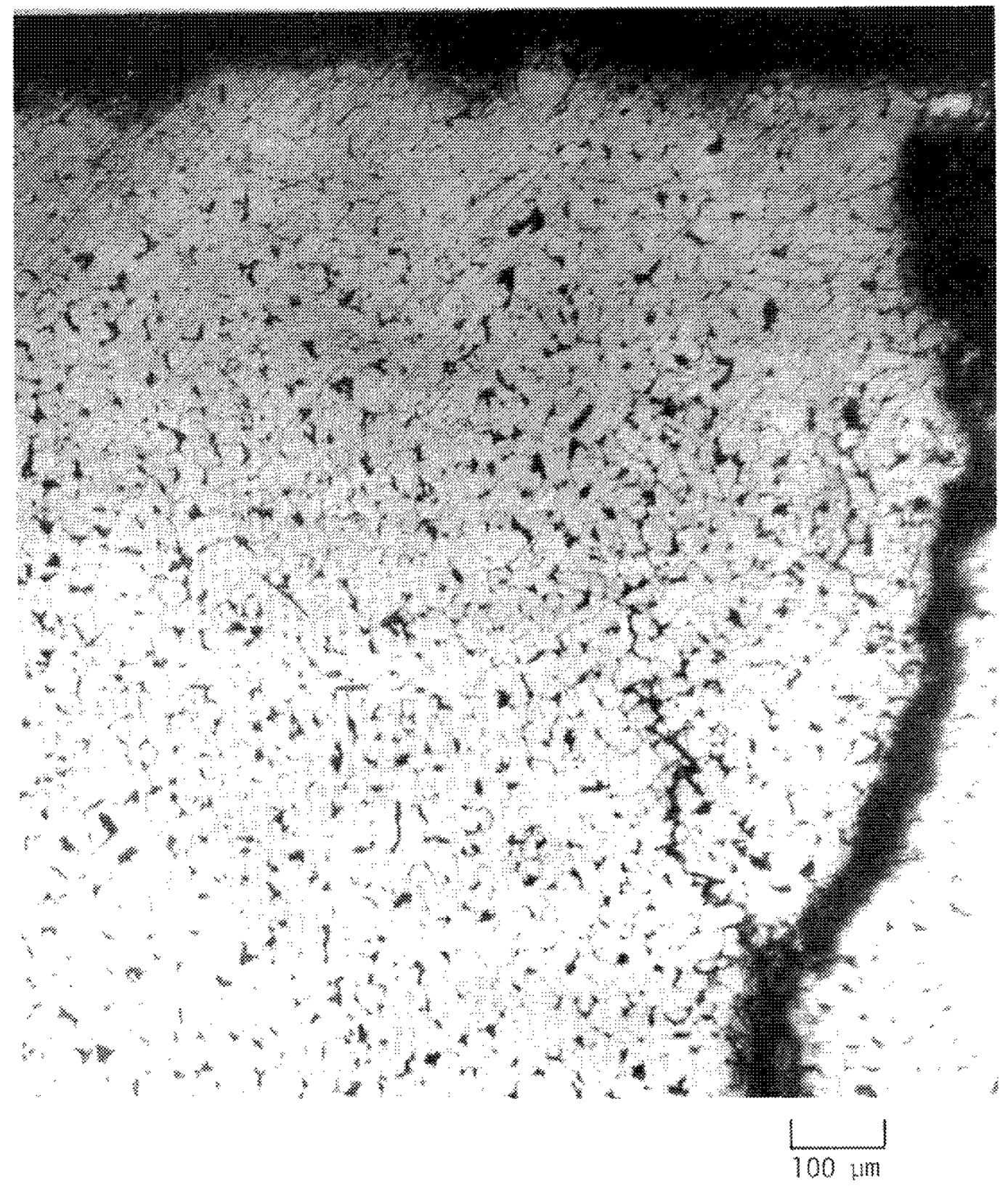

b. Crack Extending Through Wall

of Tank 16. Exterior Surface

is at Top of Photograph.

FIGURE 7. (Continued) 


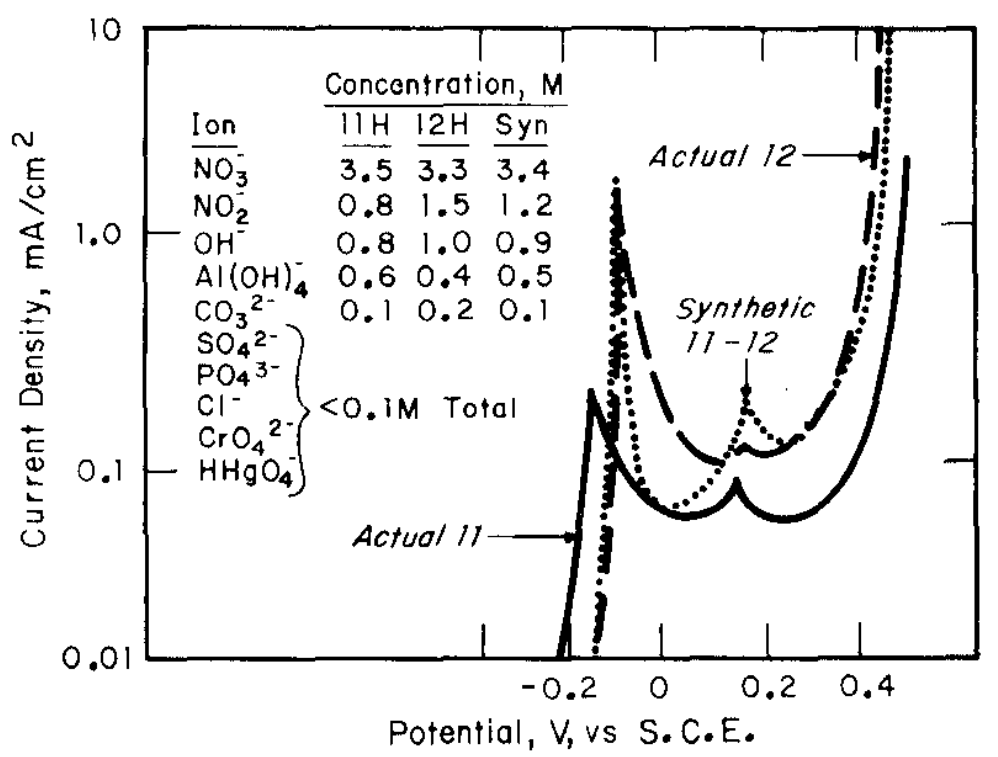

FIGURE 8. Potentiodynamic Polarization of A285-B Steel in Various Solutions ${ }^{14}$

\section{Residual Stresses and Heat Treatment}

Besides an aggressive environment, the other necessary condition for SCC is the presence of tensile stresses in the metal. In large engineering structures there are generally three types of stresses: 1) working stresses due to the load the structure was designed to carry, 2) reaction stresses - long range stresses due to fabrication, and 3) residual stresses - short range stresses due to fabrication procedures such as welding and deformation to make parts fit together.

Working stresses in such structures have been traditionally designed to be low, about $1 / 2$ or less of the yield stress of the material in accordance with the ASME Boiler and Pressure Vesse1 Code; ${ }^{5}$ this is the case for the waste tanks. Reaction stresses are difficult to estimate quantitatively. However, even though the waste tanks are large, they are simple structures, basically free-standing, right-circular vessels, that are built on stable, reinforced concrete pads. Therefore, the reaction stresses in the tanks from such phenomena as settling should be very low.

The tanks are made by welding individual preformed plates together. Since welding involves heating the metal to its melting point with subsequent cooling and solidification, contraction of the metal occurs in a localized, relatively small region. This thermal contraction is nonuniform and leads to built-in stresses 
that can exceed the yield stress of the material. Figure 9 shows the residual stresses associated with a butt weld, the most common type of weld made in fabricating the tanks. ${ }^{16}$

Cracks in the waste tanks have been predominantly associated with welds. Cracks form at right angles to the weld bead. They grow a short distance from the weld, then stop. The largest observed crack in a waste tank is six inches long. Cracks stop growing as a result of the rapid decrease of the tensile stress with distance from the weld (Figure 9), for example the particular weld in the figure might be expected to generate a crack 1 to 2 inches long.

Residual stresses can be relieved by uniformly heating a structure to a sufficiently high temperature (approximately $1100^{\circ} \mathrm{F}$ in mild steels) to allow the metal to relax because its strength decreases at elevated temperatures. Such heat treatment should eliminate SCC by removing the stress. This effect was demonstrated in the laboratory ${ }^{3}, 4$ by welding large, 3-foot square plates and exposing as-welded and stress-relieved plates to synthetic waste solutions or to $50 \% \mathrm{NaNO}_{3}$, which is a particularly aggressive solution in causing SCC. Results for the $50 \%$ $\mathrm{NaNO}_{3}$ series of tests are summarized in Table 8 . Plates that were fully stress relieved by heat treatment did not crack in 167 days; as-welded plates consistently cracked after a short exposure. Note that the "flame-washed" plates gave inconsistent results because of the difficulty in controlling the temperature in this procedure.

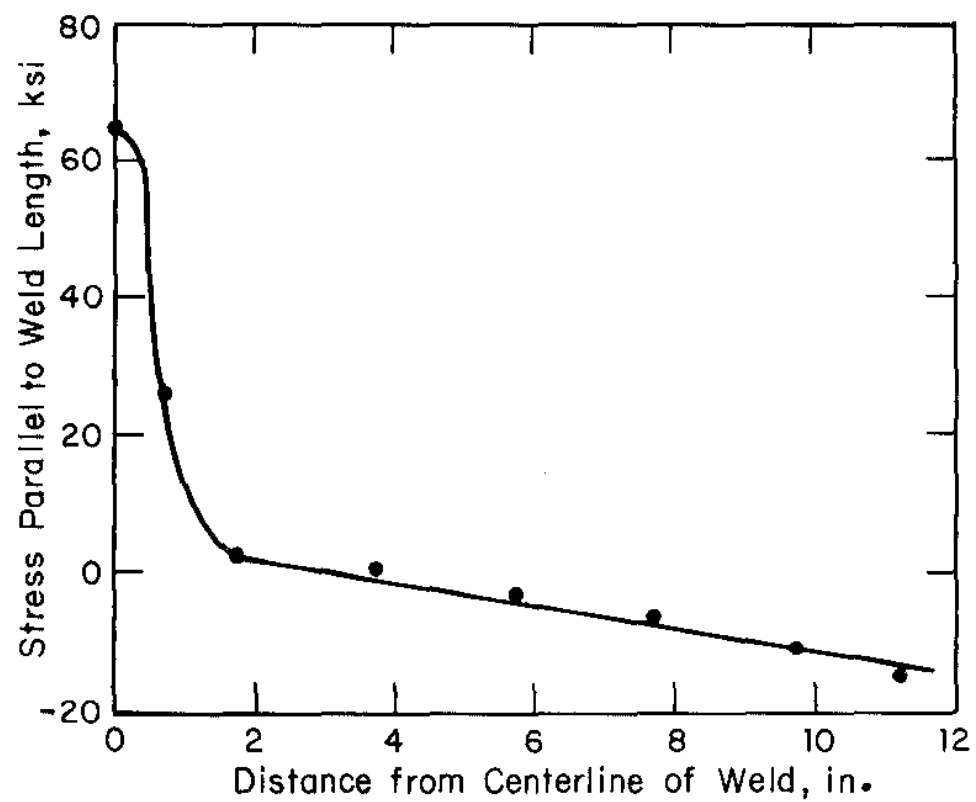

FIGURE 9. Residual Stress in Butt Welds ${ }^{16}$ 


\section{TABLE 8}

Effect of Heat Treatment on $\operatorname{scc}^{\alpha}$

$\begin{array}{rlr}\text { Specimen } & \text { Condition } & \text { Time to Crack, } \\ \text { days } & \\ 1 & \text { As welded } & 3 \\ 2 & \text { As welded } & 27 \\ 3 & \text { As welded } & 3 \\ 4 & \text { As welded } & 3 \\ 5 & \text { As welded } & 7 \\ 6 & \text { As welded } & 3 \\ 7 & \text { As welded } & 3 \\ & & \\ 8 & \text { Partial stress relief } b & 27 \\ 9 & \text { Partial stress relief } & 3 \\ 10 & \text { Partial stress relief } & 14 \\ 11 & \text { Partial stress relief } & 83 \\ 12 & \text { Partial stress relief } & \mathrm{NC} \\ 13 & \text { Partial stress relief } & \mathrm{NC} \\ & & \\ 14 & \text { Full stress relief } & \mathrm{NC} \\ 15 & \text { Full stress relief } & \mathrm{NC} \\ 16 & \text { Full stress relief } & \mathrm{NC} \\ 17 & \text { Full stress relief } & \mathrm{NC} \\ 18 & \text { Full stress relief } & \mathrm{NC} \\ 19 & \text { Full stress relief } & \mathrm{NC} \\ 20 & \text { Ful1 stress relief } & \mathrm{NC}\end{array}$

a. Welded 36-inch plates of A $285-\mathrm{B}$ exposed to $50 \% \mathrm{NaNO}_{3}$ (11.7M) at $90-95^{\circ} \mathrm{C}$ for 167 days .

b. Partial stress relief: a wide gas burner passed over welded areas.

c. NC: no cracks developed within 167 days.

d. Full stress relief: heated to $1100^{\circ} \mathrm{F}$ for 30 minutes.

On the basis of this work and other supporting 1aboratory ${ }^{17}$ and industrial ${ }^{18}$ experience on the role of residual stresses, the Type III waste tanks have been heat treated after fabrication to relieve the welding stresses. Any long range reaction stresses would also be relieved. This heat treatment is a significant advance in minimizing the probability of stress corrosion cracks in waste tanks.

Waste Composition and cracking

The waste supernate is basically an alkaline nitrate solution. Although either nitrate or caustic ions can cause mild steel to stress crack, the presence of either will inhibit 
cracking by the other. A1so, nitrite, $\mathrm{NO}_{2}^{-}$, is known to inhibit nitrate crack growth, ${ }^{19}$ and its concentration increases with aging. Therefore, the waste solution contains species that can both cause and inhibit stress corrosion cracking of the mild stee1 tanks.

The effect of waste composition was investigated in a series of laboratory studies to provide technical guidance in controlling waste compositions to minimize the probability of forming new cracks. Two different experimental techniques were used.

- The influence of solution composition on crack growth was measured in precracked stressed specimens.

- The relative loss in ductility of a tensile specimen was tested under controlled electrochemical conditions in solutions of various composition.

Precracked Stressed Specimens. For this laboratory study of the influence of waste composition, modified wedge opening loaded (WOL) specimens ${ }^{20}$ that contained a fatigue crack (Figure 10) were used. By tightening the bolt the specimen was stressed, and by relating the load to crack opening and crack length, the state of stress can be calculated. The specimen is immersed in the test solution and the crack length measured as a function of time. For this type of specimen the stress intensity, $K$, a parameter that characterizes the state of stress in the crack tip region, decreases with crack length. Therefore, the threshold stress intensity, $K_{S C C}$ (the minimum stress intensity necessary to cause corrosion cracking), is the $K$ value found when the crack ceases to grow. Values of $\mathrm{K}_{\mathrm{SCC}}$ for several solutions are given in Table 9 .

A typica1 series of crack growth curves is shown in Figure 11. In solutions that caused crack growth, the rate of growth and KSCC were independent of solution composition. This observation is evidence of the independence of crack tip chemistry from bulk solution. The initiation time, however, was related to the composition of the bulk solution, Table 9 .

From these data, a map dividing the compositional variables into cracking and noncracking regions was drawn ${ }^{19}$ as shown in Figure 12a. All solutions contained $5 \mathrm{M} \mathrm{NaNO}_{3}$ and various amounts of $\mathrm{OH}^{-}$and $\mathrm{NO}_{2}^{-}$, to approximate waste solutions. The map shows that sufficient amounts of either $\mathrm{OH}^{-}$or $\mathrm{NO}_{2}^{-}$can prevent crack growth and that they are more effective (less of either is required) if both are present. A comparison between the above data and the electrochemical tensile tests descriped below are shown in Figure $12 \mathrm{~b}$. 


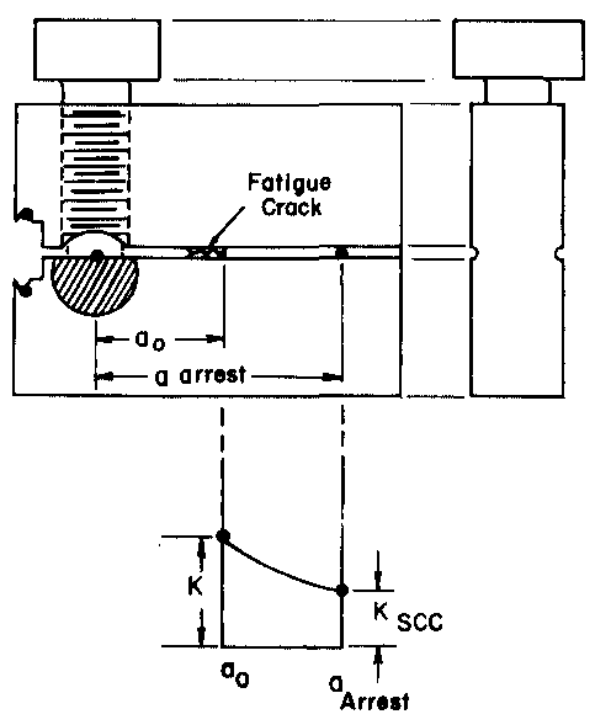

Figure 10. Modified WOL Specimen ${ }^{20}$

\section{TABLE $\dot{9}$}

Effect of Composition ${ }^{\alpha}$ on Crack Initiation

Time and $\mathrm{K}_{\mathrm{SCC}}$

\begin{tabular}{|c|c|c|c|}
\hline $\mathrm{NO}_{2}^{-}, \mathrm{M}$ & $O H^{-}, M$ & $\begin{array}{l}\text { Initiation } \\
\text { Time, hr }\end{array}$ & $\begin{array}{l}\text { Threshold Stress } \\
\text { Intensity }\left(K_{S C C}\right) \text {, } \\
M P \alpha \sqrt{m}\end{array}$ \\
\hline- & - & $75-200$ & 31 \\
\hline 0.5 & - & 200 & 31 \\
\hline 0.75 & - & 400 & 31 \\
\hline 1.5 & - & 600 & 36 \\
\hline 3.0 & - & $\mathrm{NC}^{b}$ & - \\
\hline- & 0.3 & 75 & 27 \\
\hline - & 0.5 & 400 & 33 \\
\hline - & 1.0 & 350 & 30 \\
\hline - & 1.2 & $\mathrm{NC}^{b}$ & - \\
\hline 0.2 & 0.5 & 615 & 30 \\
\hline 0.2 & 0.2 & 525 & 33 \\
\hline 0.3 & 0.3 & 1100 & 35 \\
\hline 0.5 & 0.1 & 150 & 29 \\
\hline
\end{tabular}

a. For WOL specimens in $5 \mathrm{M} \mathrm{NaNO}_{3}$ with indicated additions of $\mathrm{NO}_{2}^{-}$and $\mathrm{OH}^{-}$at $95^{\circ} \mathrm{C}$.

b. $\mathrm{NC}=$ no crack growth. 


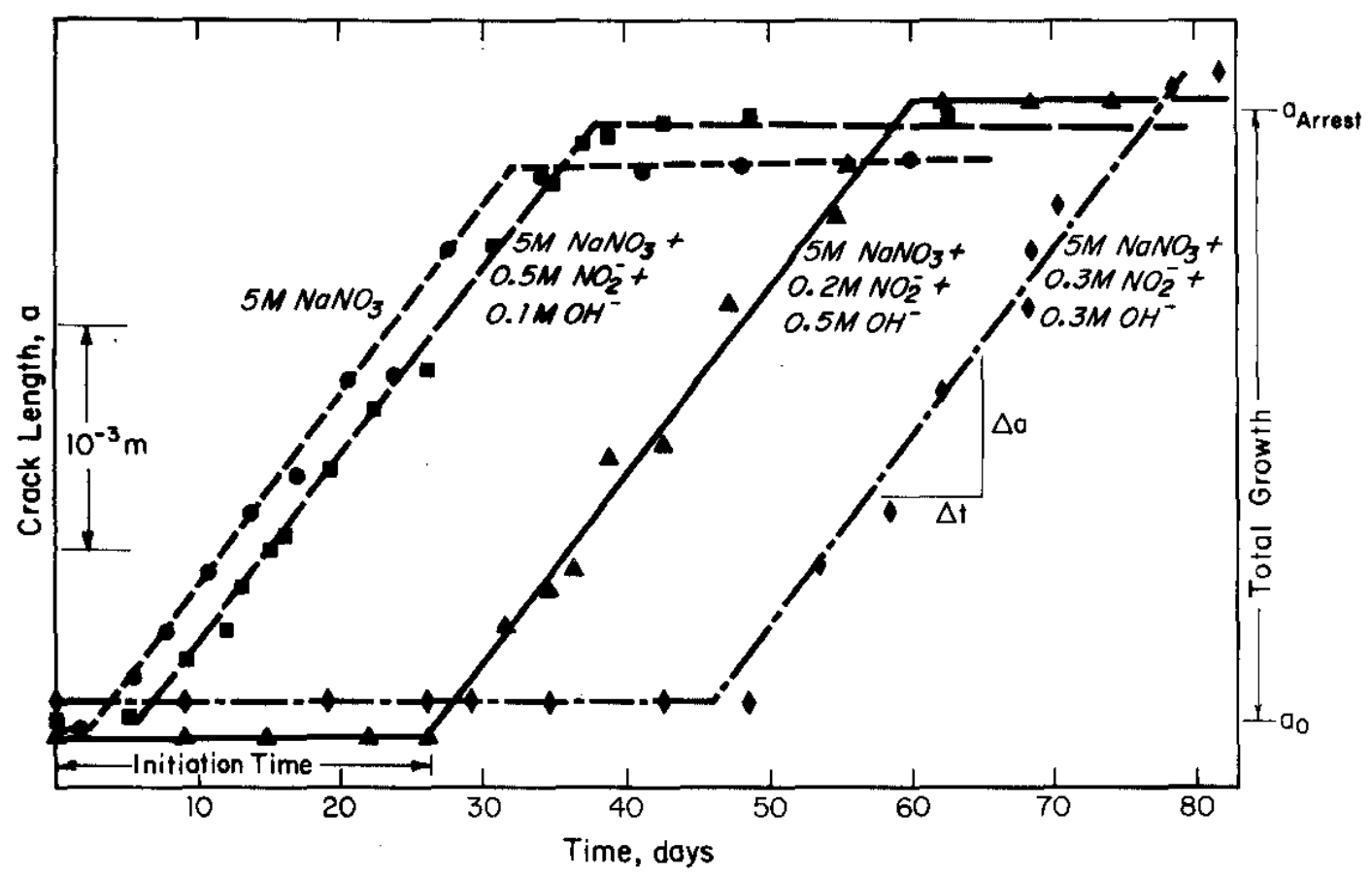

FIGURE 11. Crack Length as a Function of Time 19

Crack growth for $A 285-B$ stee 1 in $5 \mathrm{M} \mathrm{NaNO} \mathrm{N}_{3}$ solution containing additions of $\mathrm{NO}_{2}^{-}$and $\mathrm{OH}^{-}$at $97^{\circ} \mathrm{C}$. Note that $\Delta a / \Delta t$, growth rate, and total growth, which is proportional to $\mathrm{K}_{\mathrm{SCC}}$, are approximately equal for all four solutions. 


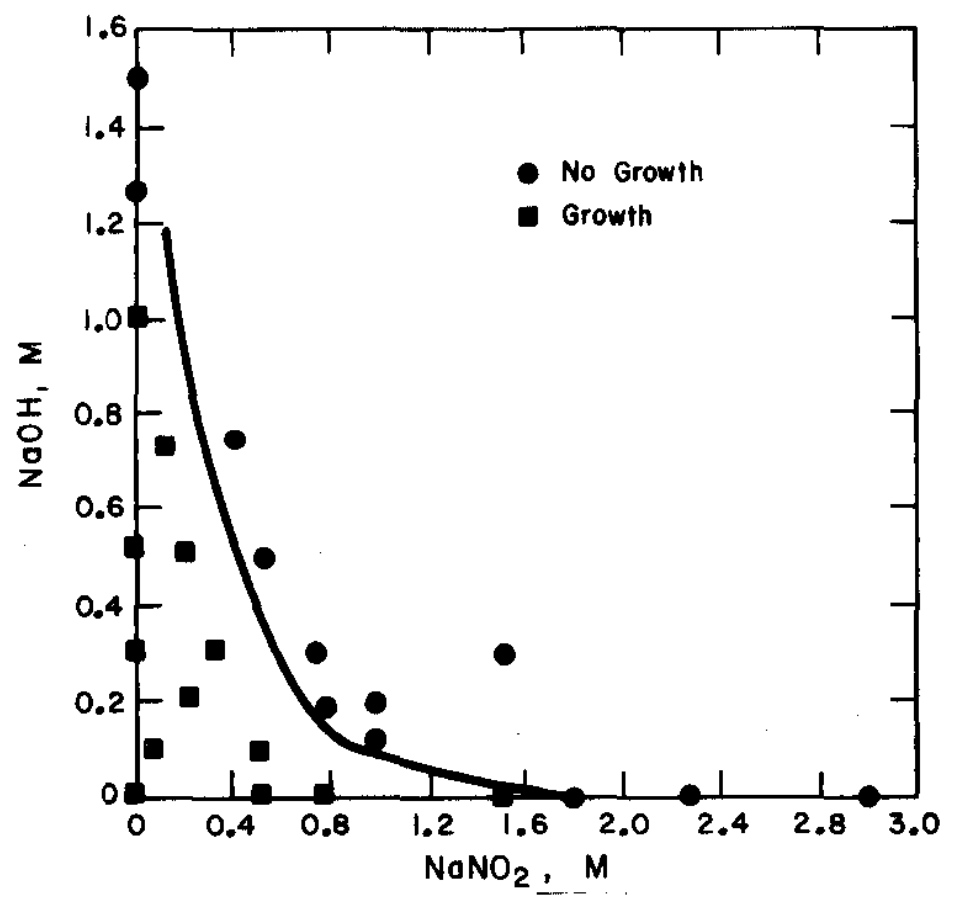

a. Data from WOL Specimens ${ }^{19}$

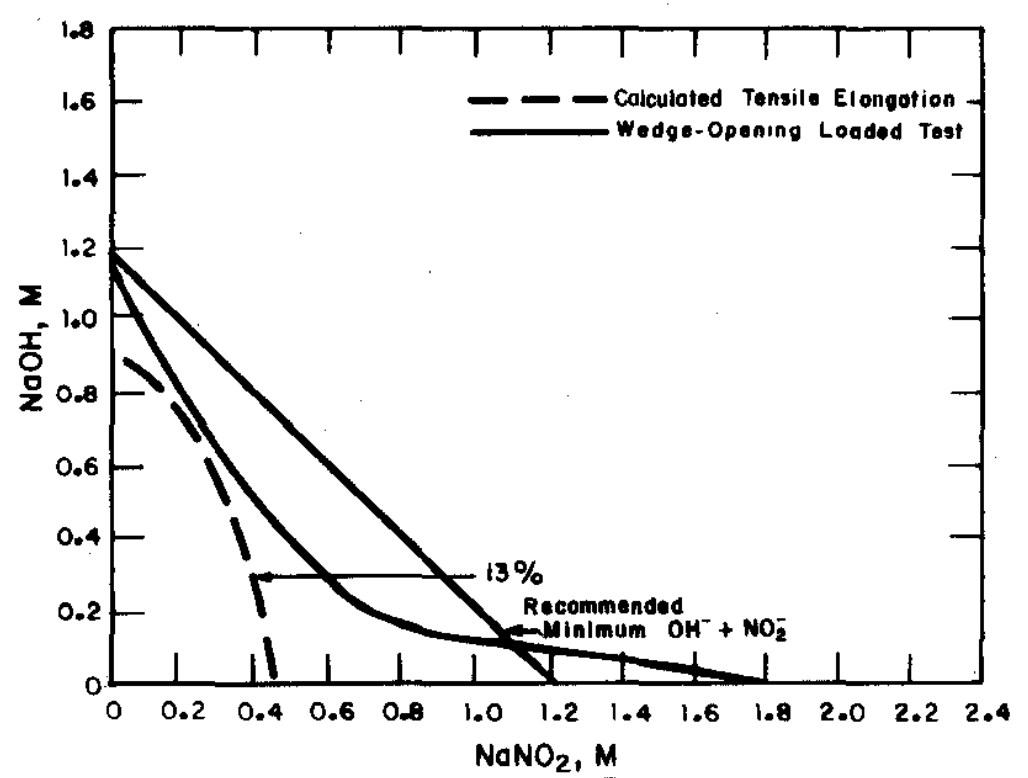

b. Comparison of WOL and Electrochemical Test Results ${ }^{14}$

FIGURE 12. Tests on Influence of $\mathrm{NO}_{2}^{-}$and $\mathrm{OH}^{-}$on Crack Growth of $A$ 285-B Steel in $5 \mathrm{M} \mathrm{NaNO}_{3}$ 


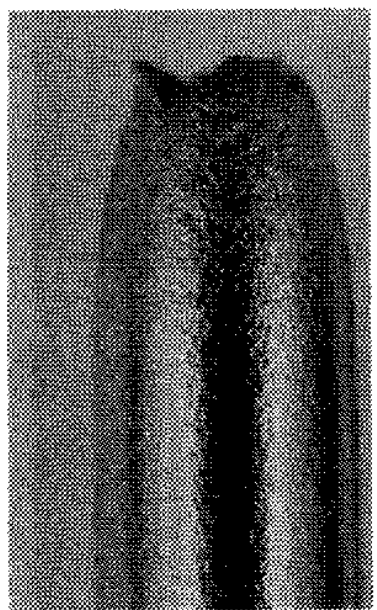

Air

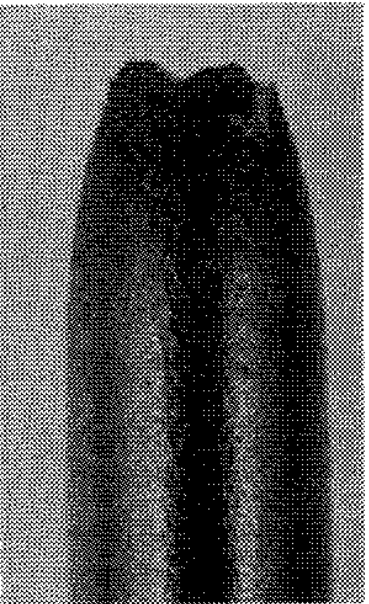

Tank I Synthetic

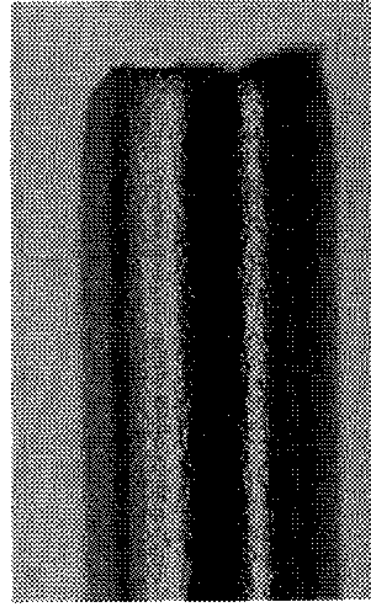

Tank 9 Synthetic

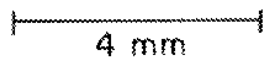

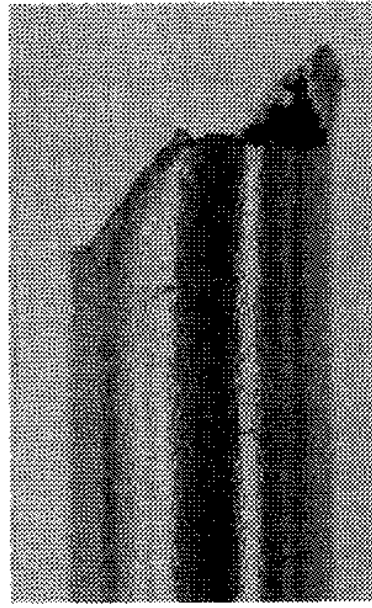

Tank 8 Symthetic

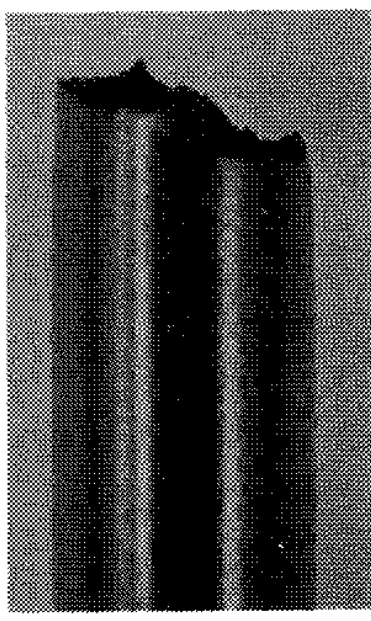

Tank 14 Synthetic

FlaURE 13. Appearance of Fractures in Electrochemical Tensile Test. 23. A 285 - 3 steel tested in various wastes at $100^{\circ} \mathrm{C}$ and $0.5 \mathrm{~mA} / \mathrm{cm}^{2}$. 
Tensize Tests with Impressed Current. A rapid test to evaluate the influence of waste solution composition on stress corrosion initiation was also developed. ${ }^{14}$ The test determines the loss of ductility when a steel tensile specimen is strained to failure. The specimen is extended at a uniform rate while acting as the anode in a controlled-current electrochemical cell with the waste solution being tested as the electrolyte. The current level was chosen on the basis of potentiodynamic polarization curves and was the same for all tests in a given series. The effects of synthetic waste solutions of various compositions compared with tests in air are illustrated in Figure 13.

The tensile strength and all of the common measures of ductility, uniform elongation, total elongation, or reduction in area, were similarly affected by the test solutions. Figure 14 shows the increase in the ultimate tensile strength with increasing $\mathrm{OH}^{-}$concentration, indicating that the presence of $\mathrm{OH}^{-}$impedes crack initiation and allows the metal to achieve its ultimate strength if enough $\mathrm{OH}^{-}$is present.

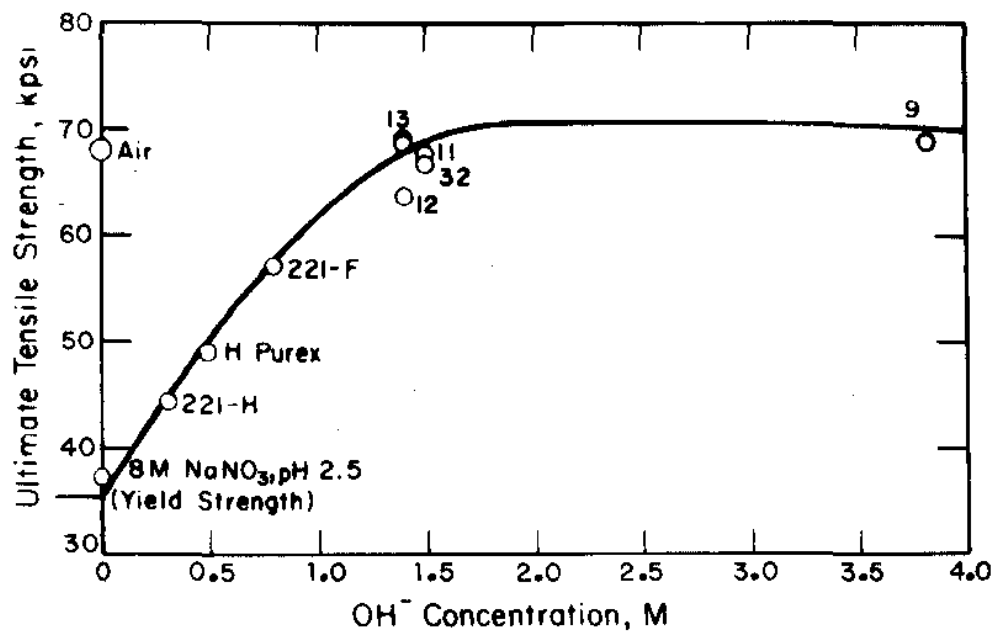

FIGURE 14. Effect of $\mathrm{OH}^{-}$Concentration on Electrochemical Tensile Test. A $285-B$ steel tested in synthetic wastes at $100^{\circ} \mathrm{C}^{22}$ and $0.2 \mathrm{~mA} / \mathrm{cm}^{2}$. 
The electrochemical tensile test data confirmed that A 516-70 steel used in Type III waste tanks is less susceptible to cracking than the A $285-B$ steel used in Types I and II tanks and that the supernates from salt receiver tanks are of the least aggressive compositions, while fresh wastes (high nitrate) are of the most aggressive ones. ${ }^{2}$ Results of recent unpublished work show that A 537-I steel has essentially the same corrosion behavior as A $516-70$ steel.

Temperature and nitrate concentration were the two solution variables that had the greatest effects on mechanical properties of the steel in two series of statistically designed experiments. Hydroxide and nitrite ions acted as inhibitors.

An equation given in Reference $e^{22}$ was derived that relates elongation of A 285-B steel in this test to the combined effect of four variables of the solution:

- Temperature from $50-100^{\circ} \mathrm{C}$

- $\mathrm{NO}_{3}^{-}$from 1.5 to $5.5 \mathrm{M}$

- $\mathrm{NO}_{2}^{-}$from 0 to $3.5 \mathrm{M}$

- $\mathrm{OH}^{-}$from 0 to $5.0 \mathrm{M}$

The test solutions also contained six ionic constituents in constant concentrations, in addition to $\mathrm{NO}_{3}^{-}, \mathrm{NO}_{2}^{-}$, and $\mathrm{OH}^{-}$to simulate waste solutions more closely. Surface cracking was observed in all specimens when total elongation in the test was less than the uniform elongation observed in air (approximately $13 \%$ ). This value was used as a figure of merit to estimate whether stress corrosion cracking of A $285-B$ steel would be a risk if the steel were exposed to equivalent solutions and temperature in service. The $13 \%$ limit agrees with results obtained for crack growth in wedge opening loaded specimens tested at $95^{\circ} \mathrm{C}$ and $5.0 \mathrm{M}$ $\mathrm{NO}_{3}^{-}$concentration with varying $\mathrm{OH}^{-}$and $\mathrm{NO}_{2}^{-}$concentrations, as shown in Figure 12b, except for differences at low hydroxide concentrations.

Effect of Temperature. Like other corrosion phenomena, the severity of stress corrosion usually increases with temperature. Both of the techniques, crack growth and the tensile tests with constant applied current, support this generalization. This is shown for A 285-B steel in synthetic 221-H waste, an aggressive solution, at three different temperatures in Table $10 .^{22}$ These data indicate that wastes as aggressive as fresh $221-\mathrm{H}$ waste should be stored at $<75^{\circ} \mathrm{C}$ if the tensile properties are an important factor in the tank performance. 
TABLE 10

Effect of Temperature on Tensile Properties ${ }^{\alpha}$

\begin{tabular}{lccc} 
& \multicolumn{3}{l}{ Per Cent of Values in Air } \\
$\begin{array}{l}\text { Temperature, } \\
{ }^{\circ} \mathrm{C}\end{array}$ & $\begin{array}{l}\text { Ditimate } \\
\text { Strength }\end{array}$ & Elongation & Reduction \\
50 & 100 & 100 & 100 \\
50 & 95 & 50 & 70 \\
75 & 65 & 30 & 20 \\
100 & 65
\end{tabular}

a. A $285-\mathrm{B}$ steel in $221-\mathrm{H}$ waste at $0.2 \mathrm{~mA} / \mathrm{cm}^{2}$.

Control of Stress Corrosion

These laboratory studies have led to a better understanding of the conditions required for stress corrosion cracks to develop in the waste tanks; consequently, appropriate fabrication procedures and process control can be applied to minimize the probability of stress corrosion cracking. Stress relief of the tanks during construction is now specified to relax the high welding stresses that caused the stress corrosion cracks associated with the welds.

During most waste storage operations, technical standards require that the composition of the wastes is controlled as shown in Table 11. A maximum $\mathrm{NO}_{3}^{-}$concentration is specified to limit the maximum aggressiveness of the supernate. The concentration of inhibitors, $\mathrm{OH}^{-}$and $\mathrm{NO}_{2}^{-}$, is maintained at specific minimum levels depending on the $\mathrm{NO}_{3}^{-}$concentration. These leve1s of $\mathrm{OH}^{-}$and $\mathrm{NO}_{2}^{-}$have been shown to prevent crack initiation in highly stressed specimens.

The temperature of fresh supernate is maintained at less than $70^{\circ} \mathrm{C}$. Since stress corrosion is a thermally activated process, the lower temperature will also inhibit the initiation and growth of cracks. The temperature limit specifically applies to fresh waste only because aged and evaporated waste contain sufficient $\mathrm{OH}^{-}$and $\mathrm{NO}_{2}^{-}$to inhibit $\mathrm{SCC}$ by themselves. 
TABLE 11

Required Minimum $\mathrm{OH}^{-}$and $\mathrm{NO}_{2}^{-}$Concentrations

in SRP Wastes

Concentration, $M$

$\begin{array}{lll}\mathrm{NO}_{3}^{-} & \mathrm{OH}^{-} & \mathrm{OH}^{-}+\mathrm{NO}_{2}^{-} \\ 3-5.5 & 0.3 & 1.2 \\ 1-3 & 0.1\left[\mathrm{NO}_{3}\right] & 0.4\left[\mathrm{NO}_{3}\right] \\ <1 & 0.01 & -\end{array}$

\section{Pitting Corrosion}

Significant pitting has not occurred on the tank walls. For example, only broad, shallow pits up to 0.020 inch deep were found on the sections removed from the wall of Tank $16^{8}$ and no pits have ever been found on corrosion samples placed in various tanks. ${ }^{6}$ The conditions required for pitting, e.g., dilute solutions and crevices, are generally not found at tank walls.

As described below, pitting attack has caused many leaks in cooling coils, however.

\section{Leaks in Cooling Coizs}

Beginning in 1966, sludge was removed from seven tanks to prepare the tanks for use as receivers of evaporator concentrate. In this operation the sludge is slurried with water and pumped to another tank. Shortly after the sludge removal, cooling coil leakage increased significantly in these tanks. Currently, 66 out of about 600 coils in the cooled tanks have developed leaks. ${ }^{7}$

In only one tank was the frequency of leaks in cooling coils unsatisfactory before sludge removal began; this occurred during a period when the pH was abnormally low due to a temporary caustic deficiency in the supernate. The deficiency was corrected by adding $\mathrm{NaOH}$. During this period, seven coils developed leaks; no others leaked in this tank until after sludge removal operations. Four coils in other tanks leaked for unknown reasons during the approximately 12 years of operation before sludge removal. 
Excluang the leaks due to low ph, cooling coils developed laks 500 times more rrequently during sludge removal, and the rate contimad to be 6 times more frequent during normal storage afterwards (figure 15). Examination of a leaking section from a cooling coil renoved fron a waste tank showed that it failed by pitting (Figure 16).

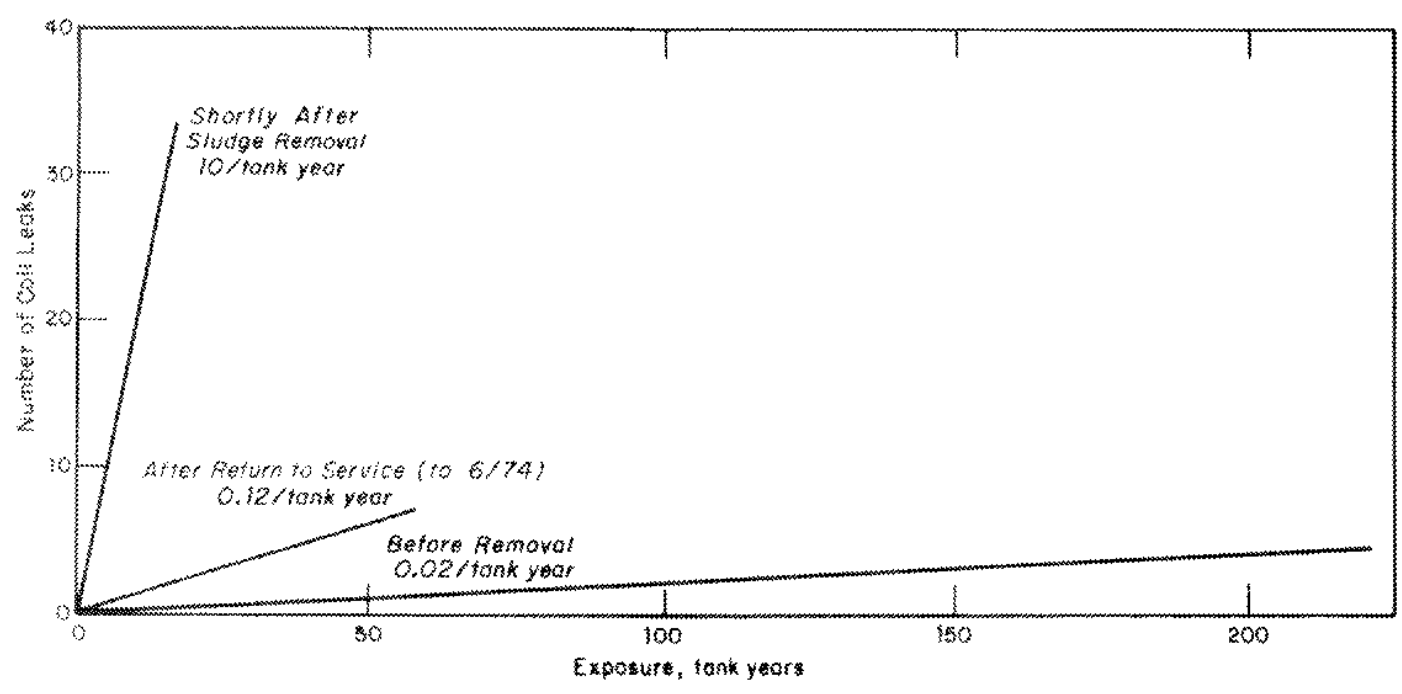

Flave 15. nncidence of cooling coll leaks, Tanks 1-9, 11-16
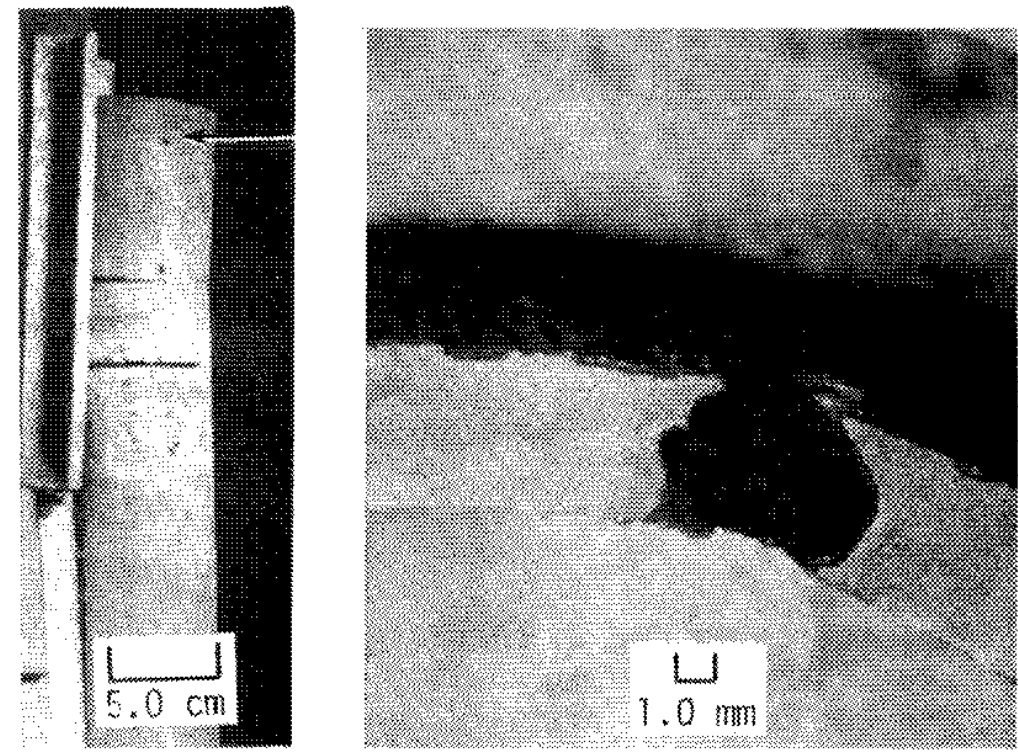

FICURE 16. Perforated Upper Horizontal Cooling Co11, Tank $2^{7}$ 


\section{Effects of Dilute Supermate}

Several explanations are needed to account for al1 leaking cooling coils. The most probable explanation for the prevalent cause of leakage during sludge removal is pitting corrosion from exposure to dilute waste that is low in caustic and nitrite and relatively high in sulfate dissolved from the sludge. In laboratory tests, diluted synthetic waste with a $\mathrm{NO}_{2}^{-}$concentration of $10^{-4}$ to $10^{-3} \mathrm{M}$, compared to 0.5 to $3 \mathrm{M}$ for normal waste, caused an increase in the pitting rate, but not a sufficient increase to account for the rapid coil failures. Sufficiently rapid attack is possible, however, when the rate increase due to inhibitor dilution is coupled with the increase in sulfate to provide a high-conductivity electrolyte and with the presence of an oxygen depletion ce11 to provide an electromotive force. Sulfate is known to increase pitting attack, ${ }^{23}$ and it is leached from the sludge during sludge removal operations. Oxygen depletion cells can be established in crevices that abound around the cooling coils. This mechanism was simulated electrochemically and pitting rates large enough to penetrate the coils in six days were observed (Figure 17).

Not all the cooling coil leaks can be explained by this rationale, or by the low $\mathrm{pH}$. Some coils probably failed from the inside due to depletion of chromate, a corrosion inhibitor, while the cooling water flow was stopped. And, some leaks appear to be due to corrosion at the liquid-air interfaces (beachline) corrosion. Investigation of these failures has not been possible because of the difficulty in locating and removing leaking sections to characterize the leaks.

\section{Control of Pitting}

Control of pitting corrosion, probably the most common cause of leaks in the cooling coils, during future sludge removal operations is planned by discontinuing the use of process water to slurry the sludge. Instead, supernate that has been diluted no more than one hundred times, or an aqueous solution with at least $500 \mathrm{ppm}$ sodium nitrite at $\mathrm{pH} 12$, will be used to provide sufficient corrosion inhibition. This practice should also prevent beachline corrosion.

Failure of the coils due to chromate depletion will be avoided by maintaining a flow of cooling water with adequate chromate to prevent pitting. Finally, control of the $\mathrm{OH}^{-}$concentration in waste will avoid acid conditions and thus prevent failure of the coils by this mechanism. 


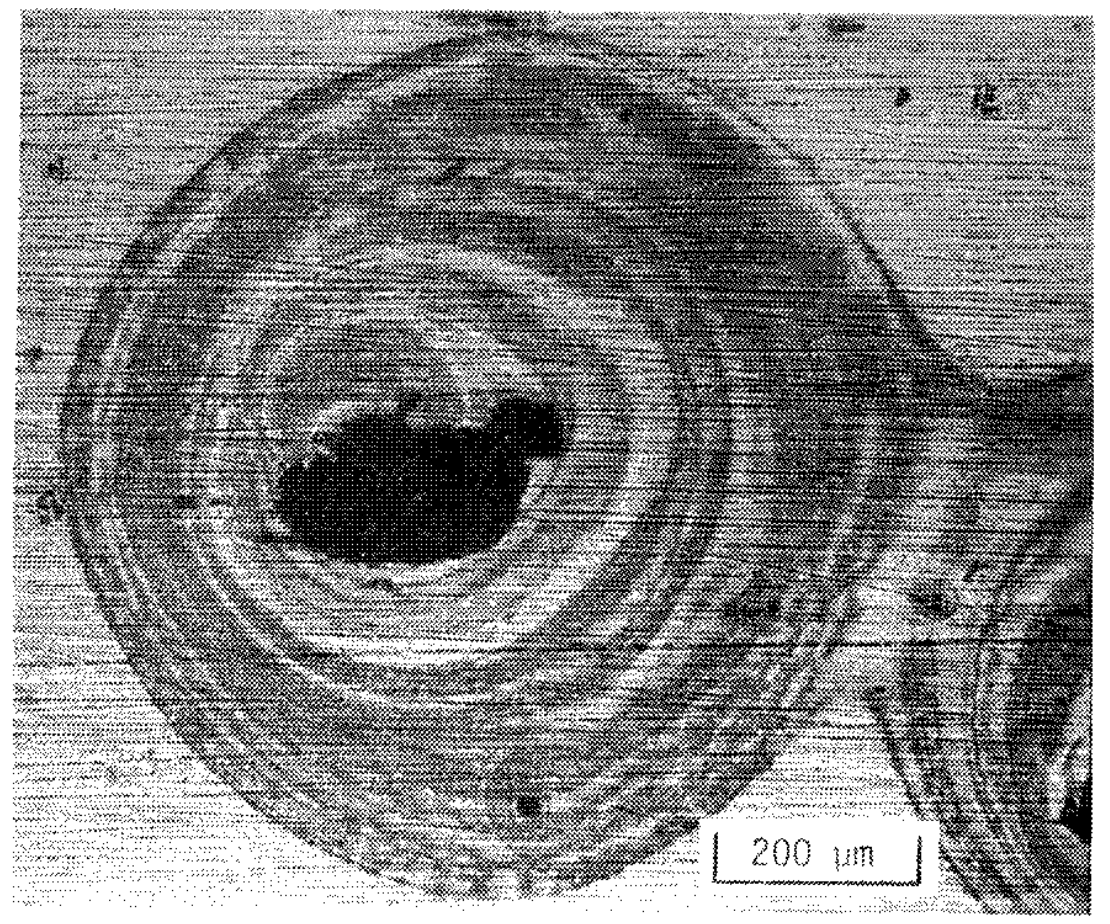

a. Actuemassive Pitting at Tenmousandfold Dilution of Tank 11 Supernate

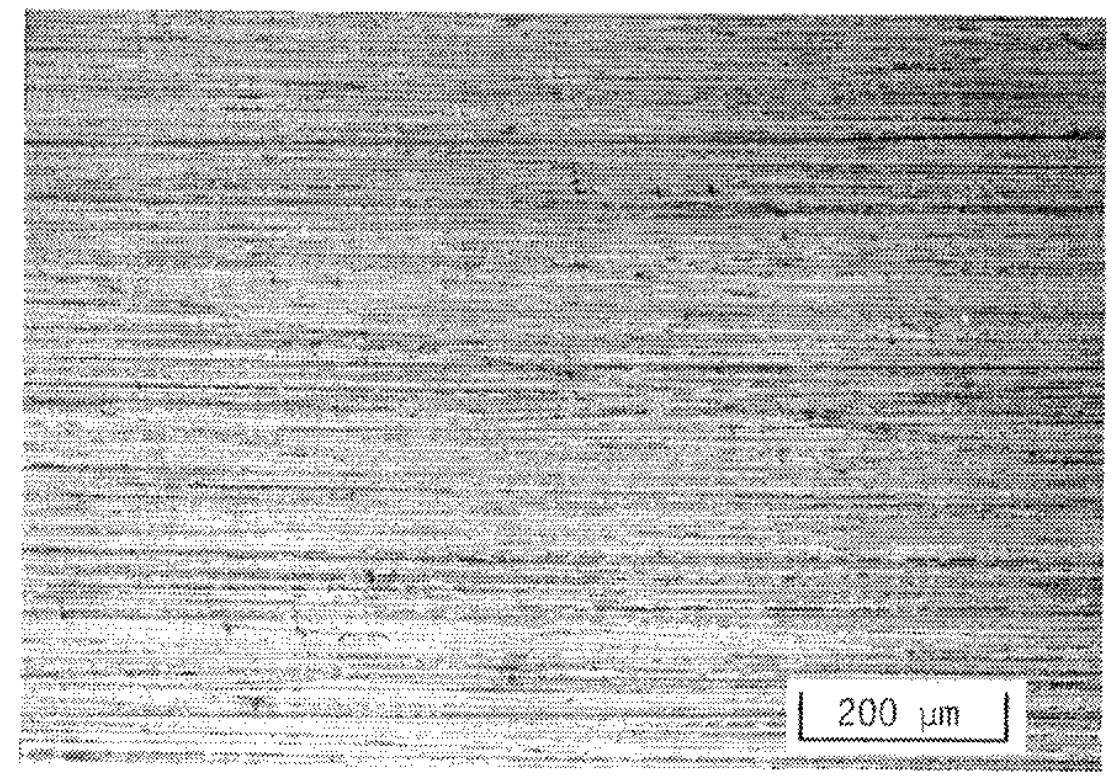

b. No Atrack at One-Wundredfold Dilution of Tank II Supernate

FlauRE 17. Electrocheulcal pitting and prevention in 


\section{FRACTURE}

Mechanical failure of an engineering structure, such as a waste tank, may be plastic or brittle. Engineering experience and well-understood design criteria have minimized the susceptibility of most structures to plastic failure by overloading. For example, the common engineering practice of fixing the design stress at one-half the yield stress of the material, as in the waste tanks, makes plastic failure improbable. However, brittle failure, failure at overall stresses less than the yield stress, is possible in structures that contain flaws (or so-called "stress raisers").

Brittle fracture depends on the local conditions in a structure such as the state of stress, flaw size, temperature, and toughness of the materia1. ${ }^{24}$ Brittle fracture may occur by two different modes, ductile or brittle, that reflect differences in the mechanism of fracture on the atomic level. In the case of mild stee1s, the temperature is very important because the steels exhibit sharp transitions in toughness in a narrow temperature range, Figure 18. At temperatures above the transition the mode of failure would be ductile, and below, brittle. The transition temperature of the steel depends on processing history, chemical composition, and thickness. For example, a normalizing heat treatment of as-rolled plate will lower its transition temperature by at least $30^{\circ} \mathrm{C}$. Normalizing consists of heating the steel to $1650^{\circ} \mathrm{F}\left(2900^{\circ} \mathrm{C}\right)$ and cooling it in air.

Brittle fracture in a ductile mode has been analyzed and requires a flaw 1 to 2 feet long with stresses equal to the yield stress of the stee1. ${ }^{25}$ The longest known crack in a waste tank is six inches. Since cracks would leak so rapidly before growing to a length of 1 to 2 feet, the waste would have to be transferred to a spare tank. For example, studies of the flow through experimentally grown cracks under simulated waste tank conditions showed that an 8.25-inch crack near the bottom of a tank wall would leak at a rate of about $2.5 \mathrm{gpm}$ (W. F. Yau to K. W. French, Private Communication, December 11, 1974) . Technical standards require that whenever the leakage exceeds $1.0 \mathrm{gpm}$, waste must be transferred to a spare tank until the leakage is reduced or the tank emptied of liquid. Therefore, brittle failure of a waste tank in a ductile mode is highly improbable.

Brittle fracture in a brittle mode can occur below the transition temperature, and be initiated by relatively small flaws. ${ }^{26}$ Therefore, the transition temperature of the steel used in the waste tanks is important. Such data are not available for the steel used in Types I and II tanks or in the early Type III tanks. However, data for A 285 Grade C steel which is very similar to the A 285-B steel are available. ${ }^{27}$ A $285-C$ steel would have a 


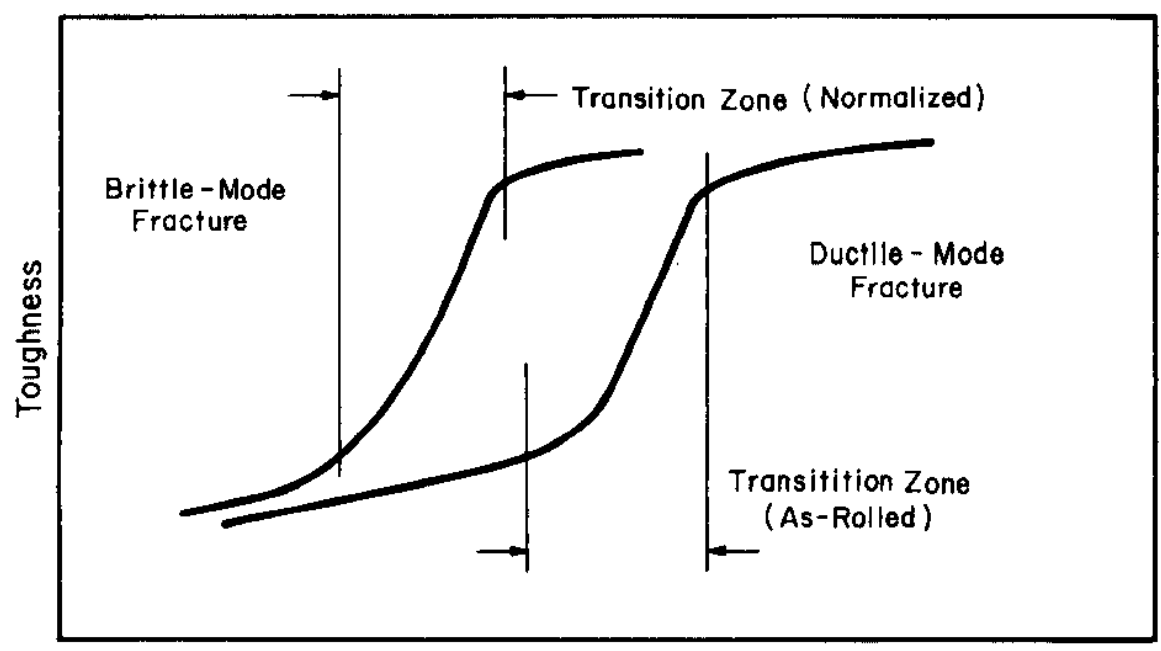

Temperature

FIGURE 18. Schematic Diagram of Toughness vs. Temperature for a Mild Steel

slightly higher transition temperature than A 285-B because of its higher carbon content, and a considerably higher transition than stress-relieved A 516-70, because of the heat treatment. Figure 19 shows the distribution of the Nil Ductility Transition Temperature (NDTT) for 61 heats of A 285-C steel derived from Charpy impact tests of plates 1 inch thick or 1ess. The data show that $99 \%$ of the steel should have NDTT's below $21^{\circ} \mathrm{C}$.

The NDTT, stress level, and flaw size, has been correlated with actual failures by the Naval Research Laboratory researchers, 26 who evolved a Fracture Analysis Diagram (FAD), Figure 20, to assist in the design of fracture safe structures. The diagram shows that the larger the flaw size, the smaller the stress required to propagate a crack and cause fracture. By maintaining the steel temperate above the NDTT, the critical flaw must be very large and therefore brittle mode fracture becomes impossible.

Heat transfer calculations have shown that the temperature of the steel in tank walls can be maintained above $21^{\circ} \mathrm{C}$ by the tank ventilation system (J. M. Boswel1, B. Crain to K. W. French, R. Maher, Private Communication, January 9, 1975). This is being done for tanks built before 1974 to minimize the probability of brittle mode failure. For brittle failure to occur the critical flaw, the yield-level stresses, and steel of low toughness must exist in the same local region. The necessary coexistence of these conditions reduces the probability of brittle failure to a very low value. 


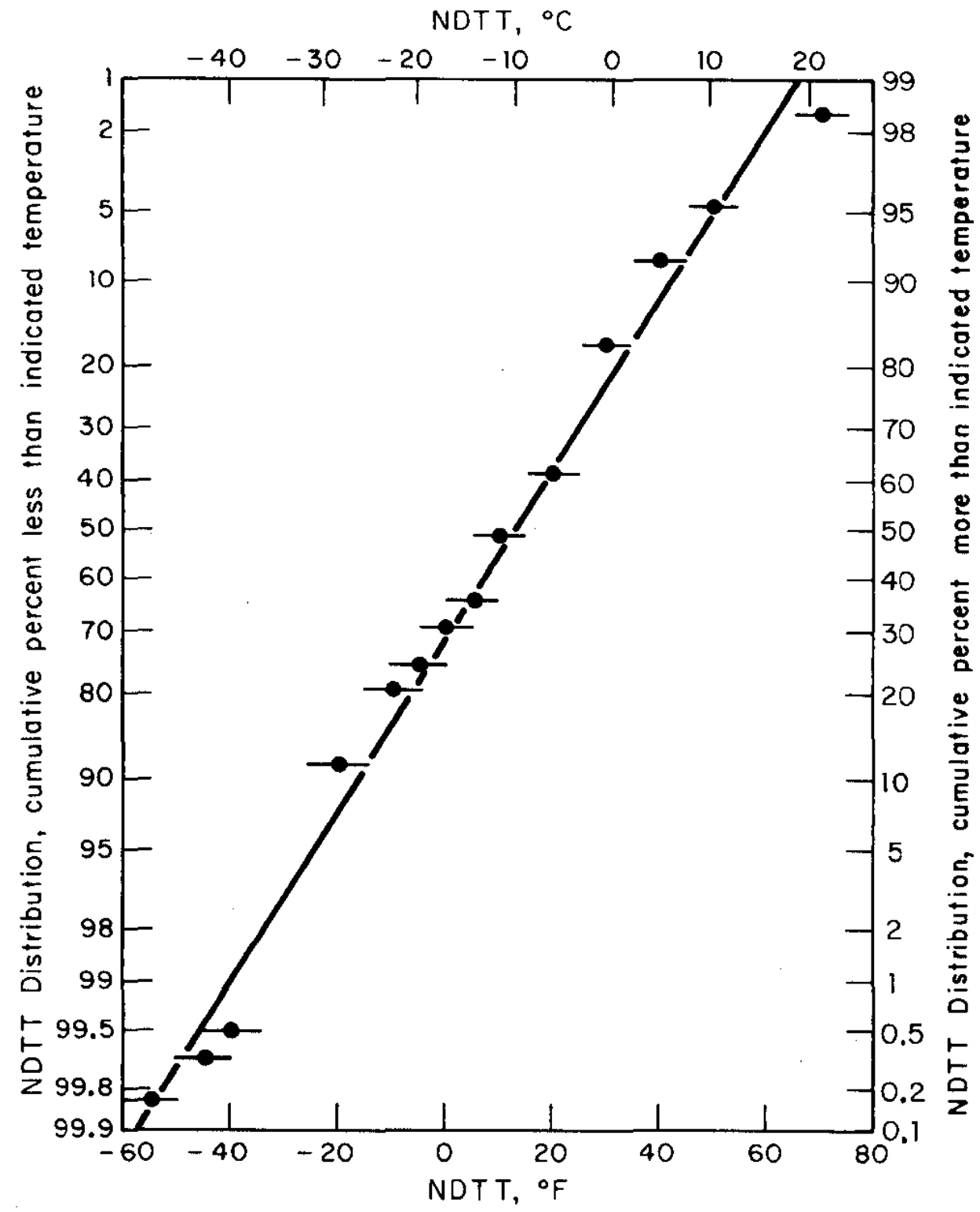

FIGURE 19. NDTT Distribution for A 285-C Stee1

Data for 61 heats. ${ }^{27}$ NDTT is taken to be $20^{\circ} \mathrm{F}$ lower than temperature for $15 \mathrm{ft}-1 \mathrm{~b}$ in Charpy impact test. ${ }^{28}$ 


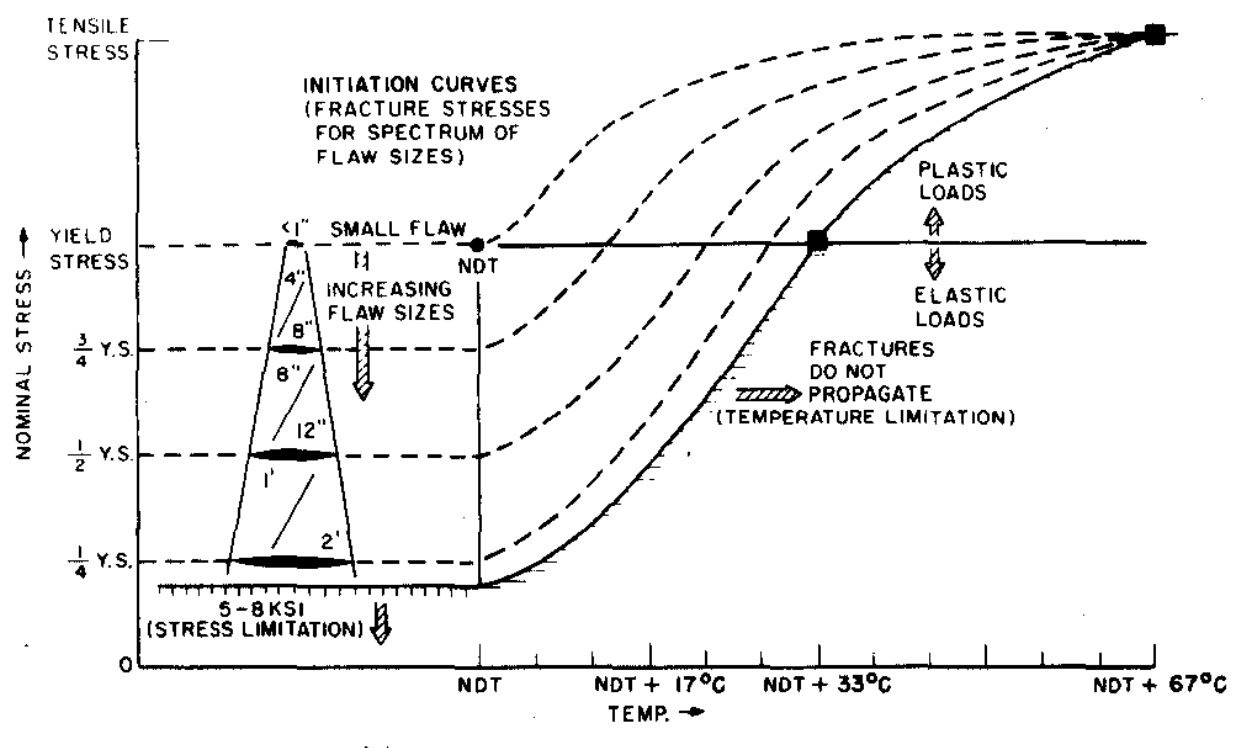

FIGURE 20. Generalized Fracture Analys is Diagram ${ }^{26}$

The toughness of the steel (and thus resistance to brittle fracture) used to build each successive group of tanks has improved as the understanding of brittle fracture of large structures has evolved. The toughness of the materials as measured by the NDTT is given in Table 12. Initially, for the Types I and II and early Type III tanks as-rolled steel was used, and the NDTT was not specified. (In fact, the drop weight test used to measure the NDTT was not developed until 1958-1960, and was not in general use until the mid-1960's.) ${ }^{28}$. For these tanks, fracture control is being achieved by assuring, to the extent possible, that the stee 1 temperature is above the NDTT by adjusting the temperature of the annulus ventilation air as described above. For the Type III tanks constructed after 1974, normalized steel will be used. A low enough NDTT is being specified so that maintaining the minimum tank wall temperatures given in Table 12 will eliminate brittle fracture as a credible failure mechanism. 
TABLE 12

NDTT of Steels Used in Waste Tank Construction

$\begin{array}{llll}\text { Tank Design } & \text { Material, Steel ALZoy } & \begin{array}{l}\text { Maximum } \\ \text { NDTT, }{ }^{\circ} \mathrm{C}\end{array} & \begin{array}{l}\text { Minimum } \\ \text { Tank Wall } \\ \text { Temperature, }{ }^{\circ} \mathrm{C}\end{array} \\ \text { Types I and II } & \text { A 285-B } & 20^{a} & 20 \\ \text { Type III } & & \\ \text { Prior to FY-1974 } & \text { A } 516-70 \text { as-rolled } & 15^{b} & 20 \\ \text { FY-1974 } & \text { A } 516-70 \text { normalized } & -18^{b} & 15 \\ \text { After FY-1974 } & \text { A } 537 \text { C1ass I } & -45^{c} & 10\end{array}$

a. From Figure 19 for $>99 \%$ of heats.

b. Unpublished data from Meta1 Properties Council.

c. Unpublished data from Lukens Stee1 Co. 


\section{REFERENCES}

1. Final Environmental Statement, Waste Management Operations, Savannah River Plant, Aiken, South Carolina. USERDA Report ERDA-1537, U. S. Energy Research and Development Administration, Washington, DC (1977).

2. Plan for Management of Radioactive Waste at Savannah River Plant. USAEC Report SRO-TWM-74-1, Savannah River Operations Office, Aiken, SC (1974).

3. M. L. Holzworth, R. M. Girdler, L. P. Costas, and W. C. Rion. "How to Prevent Stress Corrosion Cracking of Radioactive Waste Storage Tanks." Mater. Performance ?, 36 (1968).

4. L. P. Costas, M. L. Holzworth, and W. C. Rion. Stress Corrosion Cracking of Carbon Steel in Simulated Waste Solution. USAEC Report DP-1023, E. I. du Pont de Nemours \& Co., Savannah River Laboratory, Aiken, SC (1966).

5. ASME Boizer and Pressure Vessel Code, 1959, Paragraph UCS-56. American Society of Mechanical Engineers, New York (1959).

6. R. M. Girdler. Leaks in Radioactive Waste Tanks. USAEC Report DP-990, E. I. du Pont de Nemours \& Co., Savannah River Laboratory, Aiken, SC (1965).

7. R. S. Ondrejcin. Investigation of Cooling Coil Corrosion in Radioactive Waste Storage Tanks. USERDA Report DP-1425, E. I. du Pont de Nemours \& Co., Savannah River Laboratory, Aiken, SC (1977).

8. W. L. Poe. Leakage of Waste Tank 16: Amount, Fate, and Impact. USAEC Report DP-1358, E. I. du Pont de Nemours \& Co., Savannah River Laboratory, Aiken, SC (1974).

9. D. W. Tharin, R. A. Beals, and R. D. Colberg. $D_{2} O$ Tracer in Tank 21. USERDA Report DPSPU-76-11-19, E. I. du Pont de

- Nemours \& Co., Savannah River Plant, Aiken, SC (1977).

10. R. S. Ondrejcin. Composition and Corrosiveness of Low Activity Waste Supernate Stored at Savannah River Plant. USERDA Report DP-1427, E. I. du Pont de Nemours \& Co., Savannah River Laboratory, Aiken, SC (1976). 
11. R. S. Ondrejcin. Chemical Compositions of Supernates Stored in SRP High Level Waste Tanks. USAEC Report DP-1347, E. I. du Pont de Nemours \& Co., Savannah River Laboratory, Aiken, SC (1974).

12. R. N. Parkins. "The Stress Corrosion Cracking of LowStrength Ferritic Steels." The Theory of Stress Corrosion Cracking in AZloys. J. C. Scully, Ed., NATO, Brussels (1971).

13. G. Sandoz, C. T. Fuyii, and B. F. Brown. "Solution Chemistry Within Stress Corrosion Cracks in Alloy Steels." Corros. Sci. 10, 839 (1970).

14. R. S. Ondrejcin. "A Stress Corrosion Cracking Test With Slow Strain Rate and Constant Current." Presented at the ASTM Symposium on Stress Corrosion Cooling, Toronto, Canada, May 1977.

15. H. Mazille and H. Uhlig. "Effect of Temperature and Some Inhibitors on Stress Corrosion Cracking of Carbon Steels in Nitrate and Alkaline Solutions." Corrosion 28, 427 (1972).

16. W. J. Norde11 and W. J. Hall. "Two-Stage Fracturing in Welded Mild Steel Plates." Welding Joumal Res. Suppl. 44, 1245 (1965).

17. R. N. Parkins. "Stress Corrosion Cracking of Low Carbon Stee1s. P. 361 in Proc. Conf. on Fundomental Aspects of Stress Corrosion Cracking, R. W. Stahle, A. J. Forty, and D. Van Rooyen, Eds., NACE, Houston (1969).

18. M. G. Fontana and N. D. Greene. Corrosion Engineering, p 106, McGraw-Hill, New York (1967).

19. J. A. Donovan. "Factors Controlling Nitrate Cracking of Mild Steel." To be published in Conference on Envirormental Degradation of Engineering Materials, Blacksburg, VA, October 1977.

20. S. R. Novak and S. T. Rolfe. "Modified WOL Specimen for KISCC Environmental Testing." J. Mater. 4, 701 (1969).

21. R. S. Ondrejcin. "Prediction of Stress Corrosion of Carbon Steel by Nuclear Process Liquid Wastes." Trans. Amer. Nucl. Soc. 24, 241 (1976).

22. R. S. Ondrejcin. Prediction of Stress Corrosion of Carbon Steel by Nuclear Process Liquid Wastes. USERDA Report DP-1478, E. I. du Pont de Nemours \& Co., Savannah River Laboratory, Aiken, SC (to be published). 
23. H. Uhlig. Corrosion and Corrosion Control, Second Edition, p 260, John Wiley, New York (1971).

24. J. F. Knott. "Mechanics and Mechanisms of Large-Scale Brittle Fracture in Structural Metals." Mater. Sci. Eng. 7, 1 (1971).

25. W. F. Yau. "Ductile Fracture of Cracked Steel Plates." Nucl. Eng. Des. 43 (1), 1 (1978).

26. W. S. Pellini and P. P. Pyak. Fracture Analysis Diagram Procedures for the Fracture-Safe Engineering Design of Steel Structures. NRL Report 5920, U. S. Naval Research Laboratory, Washington, DC (1963).

27. F. B. Hame1. "An Investigation of the Impact Properties of Vessel Steels." Proc. Div. of Refining of American Petroleum Institute 38 (3), 239 (1958).

28. J. H. Gross. "Comparison of Charpy V-Notch and Drop-Weight Tests for Structural Steels." WeZd. Res. SuppZ. 59-S (1960). 